\title{
Lending Corruption and Bank Loan Contracting: Cross-Country Evidence
}

\begin{abstract}
Lending corruption is an important agency problem for banks. Using data from the World Bank Business Environmental Survey, we find that in countries with more corruption, banks give more favorable loan terms to borrowers. This relation is stronger when firms are under more financing constraints, consistent with corruption being important to obtaining favorable loan terms when the supply of debt capital is tighter. In line with the expectation that monitoring constrains agency problems, this relation is weaker in countries with higher foreign ownership of banks or where Protestantism is the primary religion. In the syndicated loan market, participant banks are inclined to lend less in countries where lending corruption is more prevalent. Firms in countries with greater corruption prefer private bank debt over public bonds and are more leveraged. Banks in countries with more lending corruption have poor loan quality, worse earnings performance, and are more susceptible to trouble during a financial crisis. Overall, our findings suggest that corruption greases the wheels for borrowers but is detrimental to bank shareholders.
\end{abstract}

Keywords: Lending Corruption; Bank Loan Contracting; Loan Quality; Financial Crisis JEL Classification: K4; G21; G28 


\section{INTRODUCTION}

There is a common saying that corruption is a cancer in society. A critical report on corruption by The World Bank on September 26, 2017, states, "Businesses and individuals pay an estimated $\$ 1.5$ trillion in bribes each year. This is about $2 \%$ of global GDP — and ten times the value of overseas development assistance. The harm that corruption causes to development is, in fact, a multiple of the estimated volume, given the negative impact of corruption on the poor and economic growth." The consequences of corruption in banking services can be deep and farreaching because this sector is one of the most vital of the economy. By collecting deposits and providing credit to individuals, families, and businesses, the banking system is often deemed as the lifeblood of the economy and instrumental to its growth both within and across the country (King and Levine, 1993; Rajan and Zingales, 1998; Guiso, Sapienza, and Zingales, 2004; Levine, 2005). For decades, policymakers have been struggling to promote an efficient and safe institutional environment for banking, with corruption being one of the most pervasive and difficult challenges — for policymakers, bank regulators, and banks.

In this paper, we extend the recent literature on lending corruption (e.g., Beck, DemirgucKunt, and Levine, 2006; Barth et al., 2009; Houston, Lin, and Ma, 2011; Akins, Dou, and Ng, 2017) by examining how lending corruption affects loan contracts. Similar to this literature, we refer to lending corruption as the bribery of bank officials. ${ }^{2}$ Bank officials who accept bribes pose an important agency problem within the bank as they are more likely to sacrifice the bank's interests (and those of its capital providers, including depositors) for personal gains (Bardhan, 1997; Donadelli, Fasan, and Magnanelli, 2014). Lending corruption is distinct from many other

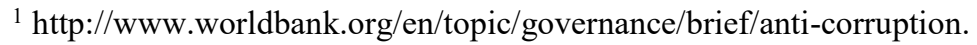

${ }^{2}$ To the extent that a loan contract is tainted by corruption, the most direct way the corruption is accomplished is likely by bribing bank officials. This is the key reason that we focus on lending corruption. Other methods could include bribing politicians or regulators to pressure the bank to grant loans with favorable terms.
} 
forms (e.g., political corruption) in that it refers specifically to the dishonest or illegal transfer of benefits directly to the lender's agents by the borrower in return for benefits to the borrowers at the time of the loan contract. Recent research on lending corruption has explored its various determinants such as bank supervision, private monitoring, and bank competition (e.g., Beck, Demirguc-Kunt, and Levine, 2006; Barth et al., 2009; Houston, Lin, and Ma, 2011). Following these studies, we rely on the voluntarily-supplied answer to the survey question in the World Business Environment Survey (WBES) on respondents' experience of dealing with corrupted bank officials in the context of borrowing for the growth and operation of businesses. Based on face-toface interviews with firm managers and owners, this survey collected the data on firms' business environment in many dimensions, including lending corruption, investment climate, and lobbying, etc. Similar to many studies that rely on survey responses to examine how country-level factors affect corporate outcomes, we take the average of the responses in each country to construct a measure of the degree of lending corruption in that country. We then link this measure to loan contracts in the country to examine how lending corruption affects loan contracting. ${ }^{3}$

Ex-ante, one might expect either a positive or negative effect of lending corruption on loan terms. On the one hand, under the bank agency cost hypothesis, the borrower gives a bribe to the bank's agent to seek a more favorable outcome. Bribery is the giving of money, goods or other forms of recompense to a recipient to induce a change in behavior (to the giver's benefit/interest) that would otherwise not occur (Tanzi, 1998). Lending corruption can be viewed from the perspective of a principal-agent framework in which there are three parties: two principals — bank

\footnotetext{
${ }^{3}$ The use of a country-level measure is driven by necessity as it is not possible to directly measure the amount of lending corruption in a specific loan contract. The respondents of the survey are presumably potential and actual borrowers. A country-level corruption level thus captures the extent to which potential and actual borrowers have to deal with corrupted bank officials. The anonymity of the survey respondents reduces the likelihood of respondent bias due to concerns about being implicated for engaging in bribery of bank officials.
} 
and borrower-and one agent, a bank official (Jensen and Meckling, 1976; Groenendijk, 1997). In this framework, the bribe renders the corrupt bank official an agent of the borrower who is incentivized to offer the borrower a more favorable outcome, to the detriment of the bank. To illustrate this point, assume that without a bribe, the loan interest rate for a $\$ 1$ million one-year loan is $10 \%$. The firm pays of a bribe of $\$ 10,000$ to the bank official, who lowers the interest rate to $6 \%$. The bank loses $\$ 40,000$, with $\$ 10,000$ going to the bank official and $\$ 30,000$ going to the borrower. In other words, within this framework, a wealth transfer takes place between the two principals and the corrupted agent, with the bank suffering from an agency cost. This wealth transfer can take many different forms; a lower interest rate is only an illustration. Granting a loan larger than optimal amount or longer than optimal duration can also benefit the borrower at the expense of the bank. Hence, in the context of a loan contract tainted by bribes to bank officials, the bank agency cost hypothesis would predict better loan terms for borrowers in countries with greater lending corruption. ${ }^{4}$

In contrast, under the protection against corruption risk hypothesis, one might argue that banks can ex-ante protect themselves from corruption by tightening the loan terms in expectation of possible corruption by their bank officials. Indeed, some studies on corruption, though not about lending corruption specifically, find that it is associated with worse loan terms. For example, Qi, Roth, and Wald (2010) find that countries with greater political corruption have a higher cost of debt for corporate bonds issued by firms. They infer that when political corruption weakens legal recourse, creditors protect against misappropriation of their capital. Weill (2011) finds that a higher level of general corruption reduces banks' willingness to lend, consistent with corruption reducing

\footnotetext{
${ }^{4}$ To the extent that one regards a corrupt bank official as also an agent of the borrower by virtue of the bribe, one can view the situation as one in which the borrower benefits from having the bank official as an agent. Hence, a corollary to the bank agency cost hypothesis could be the borrower agency benefit hypothesis.
} 
creditors' legal protection. The general intuition underlying these papers is that banks have a precontracting expectation of losses arising from the actions of the borrowers and thus establish safeguards. Similarly, one could argue that banks in countries where bribing bank officials is endemic could tighten lending policies because they have greater pre-contracting expectations that bribery of bank officials could be costly for the banks. ${ }^{5}$ It is important to note that lending corruption, unlike other forms such as political or judicial corruption, directly benefits bank officials. It is thus more ambiguous whether banks officials are willing and/or able to effectively implement safeguards to protect shareholders' interests. ${ }^{6}$ Nevertheless, to the extent that one sees banks as implementing safeguards against a culture of lending corruption, protecting against the corruption risk hypothesis would predict worse loan terms for the borrowers in places where there is greater lending corruption. ${ }^{7}$

The bank agency cost and protection against corruption risk hypotheses are not mutually exclusive. One important reason is that in any society, agency problems and actions in response to these problems is likely to be an ongoing and dynamic process. Hence, we view the effect of lending corruption on loan terms as an empirical question and a starting point for conducting richer analyses into the on-average effect.

We begin our empirical analyses by linking three key characteristics of loan contractsloan spreads, loan amounts, and loan maturity— to lending corruption across twenty-three different

\footnotetext{
${ }^{5}$ This argument is akin to the notion that when banks have higher expected loan losses from lending to riskier borrowers, they would ex-ante adjust loan policies, e.g., requiring higher interest rates or reducing loan duration, to protect their interests.

${ }^{6}$ A large agency literature highlights that when self-interest is at stake, the agent is less likely to take action, including developing and implementing policies that sacrifice their own self-interest to benefit the principal (Jensen and Meckling, 1976).

${ }^{7}$ This hypothesis does not assume that every bank official corrupt. Instead, in a place with greater lending corruption, there is a relatively higher likelihood that a bank official is corrupt. Ex ante, a bank does not know exactly who is corrupt but instead undertakes measures (e.g., charge higher interest rates) against expected corruption-related losses.
} 
countries. We find that corruption is associated with lower loan spreads, longer loan maturity, and larger loan size. These results suggest that borrowers enjoy better loan terms when lending corruption is more prevalent. To the extent that bribery induces bank officials to sacrifice the bank's interest, favorable borrower loan terms reflect wealth transfer from the banks to the borrowers. To deal with the usual endogeneity concerns in archival research, we rely on two approaches: 1) a difference-in-differences analysis relying on the anti-corruption law reforms that were carried out in a few countries and 2) an instrumental variables approach using, as instruments, various country-level variables that prior literature has suggested to be determinants of lending corruption and are arguably exogenous to the terms in individual loan contracts. We continue to find that lending corruption is linked to better loan terms.

In further analyses, we find that the positive relation between lending corruption and favorable loan terms is stronger for firms in financial distress, indicating that corruption is more important in improving loan terms when firms face greater capital constraints. This relation is weaker in countries with higher foreign bank ownership or Protestantism as its primary religion, consistent with monitoring being important in constraining bank agency problems such as lending corruption.

Next, we go beyond simply examining terms in loan contracts and study how lending corruption impacts loan syndication. We find that for loan contracts in countries with more lending corruption, there is a lower likelihood of a loan being a syndicated loan. Among syndicated loans, there are fewer participant banks and the lead bank loan allocation is higher. These findings suggest that in a country with higher lending corruption, lead banks have more difficulty in structuring syndicated loans due to concerns of potential bank agency problems related to lending corruption at the lead banks (Sufi, 2007). 
We then shift our focus from loan- to firm-level analysis by examining how lending corruption affects firms' debt choice and the capital structure. We find that where there is lending corruption (by bank officials), firms demonstrate a preference for private bank debt over public bonds and rely more on debt as a source of capital. These findings, together with the earlier results on loan terms, suggest that firms, rather than shy away from bank officials who demand bribes, make use of bribery opportunities to "grease the wheels" and engage in more advantageous debt financing. Such a choice is consistent with the earlier results that loan terms are better when greater lending corruption is present.

Finally, as discussed in the bank agency cost hypothesis, the likelihood of banks experiencing bad outcomes increases when their officials make decisions out of self-benefit and favor the borrowers to the bank's detriment. Earlier evidence on the link between lending corruption and loan terms (e.g., lower interest spreads), while suggestive of banks being adversely affected by lending corruption, does not directly address the issue of whether banks suffer when bank officials are corrupt. Consistent with corrupt agents being costly to the bank, we find that banks in countries with more lending corruption have poor loan quality, worse earnings performance, and are more likely to get into trouble during a financial crisis. The result linking lending corruption to troubled banks is an important one because troubled banks can create significant spillover effects onto other sectors of the economy, as well as onto taxpayers via bank bailouts (Gorton and Huang, 2004).

Our paper contributes in two ways. First, we contribute to the literature related to corruption in debt financing. Research in this literature typically documents results relating to general corruption and political corruption/connection. Using bank loans in Pakistan, Khwaja and Mian (2005) find that politically connected firms can obtain bank loans more easily but have higher 
default rates. This effect is primarily driven by state-owned banks. A similar study by Houston et al. (2014) examines the impact of political connections on the cost of debt in a US setting. They find that firms with politically connected board members enjoy a lower cost of debt. Detragiache, Tressel, and Gupta (2008) find that general corruption is negatively correlated with bank credit to the private sector. Weill (2011) finds that a higher level of corruption is negatively correlated with banks' willingness to lend, consistent with the notion that corruption increases the uncertainties about judicial decisions for banks and thus decreases the legal protections for creditors. Park (2012) documents that non-performing loans increase in countries plagued by higher corruption among public officials and politicians; they attribute this finding to the bribery of politicians reducing bank soundness.

Our paper complements and contrasts with the existing literature by focusing specifically on lending corruption, as opposed to the public sector or political corruption. As noted earlier, lending corruption is that which is specific to the parties involved in loan contracting. To conduct a comprehensive analysis of this issue, we examine how lending corruption affects the terms in individual loan contracts, as well as several corporate-level outcomes for borrowers and lenders. Our large-sample empirical study takes a multi-faceted view of the contracting issue by first looking at the impact on the loan terms, then the choices and outcomes of the contracting parties. ${ }^{8}$ Taken together, our evidence indicates that corrupt bank officials, while greasing wheels for the borrower, are harmful to the banks.

Second, our paper contributes to the cross-country bank loan contracting literature (e.g., Qian and Strahan, 2007; Bae and Goyal, 2009; Kim, Tsui, and Yi, 2011; Giannetti and Yafeh, 2012; Chen et al., 2016). A strand of literature investigates the impact of legal environments on

\footnotetext{
${ }^{8}$ Some studies consider how business contracts are influenced by corruption, typically in the form of case studies and news reports (Bhargava and Bolongaita, 2004; Ratley, 2014; New York Times, 2015).
} 
bank loan contracting (Qian and Strahan, 2007; Bae and Goyal, 2009). They find that in countries with stronger legal enforcement and better creditor protections, bank loans are more likely to have a lower interest rate, larger size, and longer maturity. Kim, Tsui, and Yi (2011) investigate the effect of IFRS adoption on bank loan contracting and find that IFRS adopters have a lower cost of debt, larger loan size, and longer maturity. Another vein of the literature shifts studies informal institutions. Giannetti and Yafeh (2012) find that cultural differences between lenders and borrowers lead to a higher cost of debt, smaller loan size, and shorter maturity. Chen et al. (2016) find that religiosity is negatively related to the cost of a bank loan. We extend the prior literature by documenting that bribing loan officials also plays an important role in these contracts. To the extent that more favorable loan terms are viewed as wealth transfers from the banks to the bribers, we also document that formal institutions (deposit insurance) and informal institutions (religion) can affect wealth transfers driven by corruption.

The rest of this paper is organized as follows. We discuss the relevant literature in Section 2, describe the data and sample and present the research design in Section 3. We discuss the results in Section 4 and provide robustness checks in Section 5. We conclude our research in Section 6.

\section{LITERATURE REVIEW}

In research linking corruption to economic development, several studies indicate that corruption has negative effects on private investment, government expenditure, human capital development, foreign direct investment, and international aid effectiveness (e.g., Murphy, Shleifer, and Vishny, 1993; Shleifer and Vishny, 1993; Bardhan, 1997; Ehrlich and Lui, 1999; Mauro, 1995;

Wei, 2000; Mo, 2001; Aidt, 2009). For example, Mauro (1995) finds that corruption lowers private investment, thereby lowering economic growth. Mo (2001) documents that corruption significantly reduces economic growth through the very important channel of political instability. 
Some economists take the somewhat controversial view that corruption might be economically beneficial. In a country where bureaucracy is ubiquitous, corruption can help cut through red tape and may not be an obstacle to economic growth (Leff, 1964; Leys, 1965; Huntington, 2002; Aidt, 2003). In other words, entrepreneurs may find more willing to start new companies and firms can invest more easily if they can use "speed money" to facilitate borrowing and mitigate the distortions that arise from ill-functioning institutions. Lui (1985) theoretically demonstrates that corruption may be an efficient way of reducing the time cost of queues. Meon and Weill (2010) find that corruption is less detrimental to efficiency in countries where institutions are less effective. They find that corruption may even be positively associated with efficiency in countries with extremely ineffective institutions. In fact, both South Korea and Indonesia saw their economies boom despite of rampant graft and corruption during the post-war years.

The literature on corruption tends to focus on that of politicians or government agencies. However, there is also significant private sector corruption. In particular, the banking system is one area where corruption is a major problem, especially in developing countries (Barth, Caprio, and Levine, 2006). In addition, lending corruption can be very costly because when bank managers lend depositors' money to businesses not solely based on efficiency considerations, fewer funds are available to support more credible and deserving business activities (Barth et al., 2009).

Perhaps not surprisingly, many real-life cases of corruption take place within the banking sector where bank officials are offered bribes to grant loans. Here are some anecdotes about lending corruption in both developing and developed countries:

Russia: "The traditional envelopes (and later briefcases) filled with cash were replaced by low-interest credits" (Levin and Satarov, 2000). 
India: "Instances of borrowers taking care of a senior banker's child's education overseas or picking up the tab for wedding reception of the daughter and even honeymoon at Bali are not rare. There are also borrowers who offer "annuity" to bank chiefs after their retirement to express their gratitude for the support extended to them in appraisal of loan proposals and disbursements of loans." (Bandyopadhyay, 2016)

United States: "More than 100 former Wells Fargo loan officers accepted kickbacksincluding one former employee's wife who collected tens of thousands of dollars in payments" (The New York Times, 2015).

Given human nature and secrecy of lending corruption, available reports of corruption in the banking sector are likely to reflect only the tip of the iceberg. While such corruption has come under the media spotlight in recent years, it has also attracted the attention of many academic researchers, with several studies examining the determinants of bank/lending corruption. For example, Beck, Demirguc-Kunt, and Levine (2006) show that traditional official supervision does not constrain lending corruption, but the private monitoring of banks through the timely disclosure of accurate information can reduce it. Barth et al. (2009) and Houston, Lin, and Ma (2011) find that banking competition and information sharing can help lower lending corruption, while the state ownership of media and media concentration increases it. In a recent study by Akins, Dou, and $\mathrm{Ng}$ (2017), the effect of country-level timely loan loss recognition by banks is shown to help constrain lending corruption because it increases the probability that troubled loans will be uncovered.

Despite a number of factors having been shown to determine lending corruption, there has been limited direct research into the relation between lending corruption and loan contracts. Having a better understanding of such a relationship is important because banks play an important 
role in credit provision in the economy through the formation of loan contracts (e.g., Diamond and Dybvig, 1983; Demirguc-Kunt, Feven, and Levine, 2013). To the extent that the lending contract is tainted by corruption, the most common way to engage in corruption is likely to be through bribing bank officials; as noted earlier, in the analysis that follows we refer to such bribery as lending corruption. In particular, we extend the existing literature on lending corruption by examining the effect of lending corruption on bank lending. To the best of our knowledge, our paper is the first to examine the link between the bribing of bank officials and loan contracts.

\section{DATA}

\subsection{Measurement of Lending Corruption}

While corruption is undoubtedly an important issue, studying issues related to it has been challenging because it is difficult to measure. Some studies have attempted to measure corruption using an epidemiological approach (Fernández, 2011; Liu, 2016), that is, when individuals emigrate from their native country to a new one, their culture of corruption travels with them and is inherited by their descendants. Some studies have relied on legal cases of corruption in court, a typical measure of political corruption (Smith, 2016; Dass, Nanda, and Xiao, 2017). Other studies, including ours, have relied on surveys (Beck, Demirguc-Kunt, and Levine, 2006; Barth et al., 2009; Houston, Lin, and Ma, 2011; Zheng et al., 2013; Akins, Dou, and Ng, 2017). Each method has its advantages and disadvantages and is more suited to some settings than others.

In our setting, our key explanatory variable of interest is Lending Corruption, which we construct using data from the World Business Environment Survey (WBES 2000) conducted by the World Bank in 1999-2000. Using face-to-face interviews with owners, managers, directors, or the employees of companies over late 1999 and early 2000, this survey is designed to generate measures on lending corruption, lobbying, judiciary system, and other factors in the business 
environment in 80 different countries that cover emerging, developing, and developed economies. Many studies have used response to the question about the lending corruption to study issues related bribery of bank officials (e.g., Beck, Demirguc-Kunt, and Levine, 2006; Barth et al., 2009; Houston, Lin, and Ma, 2011; Zheng et al., 2013; Akins, Dou, and Ng, 2017). Specifically, the question is: "Is the corruption of bank officials an obstacle for the operation and growth of your business?" The response to this question ranges from 1 to 4 , with higher values indicating higher levels of lending corruption.

In our study, we construct a country-level measure, Lending Corruption, using firms' responses to the above question: Similar to how many country-level indices are constructed in the literature and by many international organizations, we compute Lending Corruption by take the average of the responses in each country. ${ }^{10}$

There are at least three key advantages to using this data to study corruption within the banking system. First and foremost, the survey question is specifically related to lending corruption. Corruption is inherently complex practice-depending on the different parties involved (e.g., bribe-givers vs. bribe-takers), one might expect different outcomes depending on the specific nature of the corruption. ${ }^{11}$ This survey provides direct measurement on bribery of bank officials in the loan contracting process. Second, the survey question is also crafted in a way that solicits honest feedback from the respondents. In particular, the question does not ask whether the

\footnotetext{
${ }^{9}$ Beck, Demirguc-Kunt, and Levine (2006) present an extensive discussion of this lending corruption measure. ${ }^{10}$ Following Edwards (1992) and Chen et al (2016), we also construct an alternative weighted lending corruption index for each country. We use the number of survey responses in each country as the weight. All of our results are robust to using this alternative index.

${ }^{11}$ For example, the corruption of foreign public officials (e.g., Pacini, Swingen, and Rogers, 2002) might have no effect on loan contracting because it is unlikely that foreign public officials are involved in the loan contracting process within a country. Political corruption within the country might lead to weaker creditor rights postcontracting and banks ex-ante trying to protect against weaker rights (e.g., Qi, Roth, and Wald, 2010; Weill, 2011). Lending corruption typically takes place pre-contracting and affects loan decisions. The key party in this form of corruption is the bank official and hence, there is a bank agency problem that does not exist other forms of corruption.
} 
respondent has participated in any lending corruption. Instead, it asks the extent to which lending corruption is a hindrance to the business. The survey's anonymity also helps to reduce bias in the response. Third, this survey provides comprehensive coverage on firms of various sizes, industries, and ownership within each country. One could regard the respondents as being actual or potential borrowers. A limitation of the survey data, however, is that the lending corruption question was only asked in the year 2000 survey, not in subsequent surveys. ${ }^{12}$ However, we believe that a culture of lending corruption or any form of corruption within a country is unlikely to change over a short period.

\subsection{Measurement of Bank Loan Contracts}

To examine the effects of lending corruption on bank loan contracting, we study both the pricing (Loan Spread) and non-pricing terms (Loan Size and Loan Maturity) of bank loan contracts and use them as our dependent variables. In particular, we use all-in-spread drawn, that is, the interest spread over LIBOR plus associated loan origination fees as the measure of the loan spread or interest rate. For the non-pricing terms, we use the loan amount in billions of US dollars as measures of loan size, and the time to mature in months as measures of loan maturity. We take the natural logarithm of each of the three variables when we perform the regression analysis.

\subsection{Sample}

The unit of our analysis is at the firm-loan level. We obtain bank loan data from Dealscan, which contains detailed loan information (e.g., loan spread, loan size, loan maturity, loan types, etc.) from 34 countries. We use the linking table provided by Chava and Roberts (2008) to match the bank loan data with borrowers' financial information in the Compustat Global database. It is worth to note that over half of the non-US bank loans do not have loan spread information in

\footnotetext{
${ }^{12}$ For most countries, the WBES is conducted every 3 or 4 years.
} 
Dealscan. To maximize the sample size, we follow Qian and Strahan (2007) and Kim, Tsui, and Yi (2011) and require bank loan facilities to have data only on non-pricing terms (i.e., Loan Size and Loan Maturity). We then use the matched firm-loan data to merge with the WBES survey and we are left with a sample of 23 countries. We further exclude firms in the utilities and finance industries since they are highly regulated and their financial reporting is different from other firms. We also control for a series of country-level characteristics, including GDP, economic growth, inflation, the rule of law, law origination, political and creditor rights protection, and public sector corruption. Appendix A presents sources for these data. By excluding observations that lack the necessary data to construct the control variables used in our empirical tests, our final sample consists of 31,414 bank loan facilities made in 23 countries from 1995 to $2005 .{ }^{13}$ Assuming the WBES captures the lending corruption deeply rooted in a country's social and political values, we impute its results from 2000 to all the years in our sample. ${ }^{14}$ We choose 1995 as the initial year because few non-US bank loans are covered by Dealscan until the middle of the 1990s (Qian and Stranhan, 2007). Since the lending corruption data are from WBES (2000), to get a balanced sample, we choose 2005 as the final year of our sample. ${ }^{15}$

\subsection{Research Design}

To evaluate the impact of lending corruption on the bank loan contracting terms, we estimate the following empirical model:

\footnotetext{
${ }^{13}$ The twenty-three countries are Argentina, Brazil, Canada, Chile, Egypt, France, Germany, India, Indonesia, Italy, Malaysia, Mexico, Pakistan, Peru, Philippines, Singapore, South Africa, Spain, Sweden, Thailand, Turkey, the USA, and the United Kingdom. Eleven countries are dropped due to missing lending corruption information, including Australia, Finland, Hong Kong, Israel, Japan, Netherlands, New Zealand, Norway, South Korea, Switzerland, and Taiwan.

${ }^{14}$ In a different setting, Favara, Schroth, and Valta (2012) and Favara et al. (2017) also choose to impute a survey result to a 10 year interval (pre and post 5 years). We therefore believe the interval from 1995 to 2005 is a reasonable window of time for our study.

${ }^{15}$ In a robustness test, we change the sample interval from 10 to 20 years. We use 1990 to 2010 as the sample interval and find that our results are still robust.
} 
Bank Loan Contracting Measures $=f\{$ Lending Corruption, Loan Terms Controls, Firmlevel Controls, Country-level Controls, Industry and Year fixed effects $\}$.

In the regression, the dependent variables are one of the three bank loan terms: the cost of debt $(\mathrm{Ln}$ (Loan Spread)), loan size (Ln (Loan Size)), and loan maturity (Ln (Loan Maturity)). We include industry and year fixed effects. The industry fixed effects control for all time-invariant industry characteristics, and year fixed effects condition out the influences of time-series trends. Drawing on prior studies on the determinants of the costs of bank loans (Qian and Strahan, 2007; Graham, Li, and Qiu, 2008; Qi, Roth, and Wald, 2010; Kim, Tsui, and Yi, 2011; Chen et al., 2016), we control for a series of loan-, borrower-, and country-level variables in our baseline model. First, we include a set of bank loan-related terms including loan size, loan maturity, and performance pricing. Second, we include firm-level (i.e., borrower-level) characteristics: Ln (Firm Size) is the natural logarithm of total assets. Tangibility is gross property, plant, and equipment scaled by total assets. Leverage is current and long-term debt scaled by total assets. $R O A$ is pre-tax income scaled by total assets. Finally, we include a series of country-level controls that may affect the loan contracting terms. In particular, we control for the following variables: $L n(G D P)$ is the natural logarithm of GDP per capita in US dollars. Economic Growth is the GDP growth rate. Inflation is the inflation rate measured by CPI. English (French, German) Law is an indicator variable that equals one if the origin of the company law or the country's commercial code is English Common (French Civil, German Civil) Law, zero otherwise. Rule of Law refers to the assessment of the law and order tradition in the country produced by the country-risk rating agency International Country Risk (ICR), scaling from 0 to 10 with a higher score indicating more of a tradition of law and order. Political Rights is an index provided by Freedom House that evaluates the degree of freedom in the electoral process, political pluralism and participation, and the functioning of government; it 
ranges from 1 (strong political rights) to 7 (weak rights). Creditor Rights refers to the creditor rights index proposed by La Porta et al. $(1998,1999)$ which measures the legal rights of creditors against defaulting debtors in different jurisdictions. This index ranges from 0 to 4 , with higher values indicating stronger creditor power. Public Sector Corruption is measured as (-1)*Control of Corruption, which captures perceptions of the extent to which public power is exercised for private gain, including both petty and grand forms of corruption, as well as capture of the state by elites and private interests. This index ranges from -2.19 to 1.04 . Higher values of Public Sector Corruption indicate higher levels of corruption.

\subsection{Descriptive Statistics}

Table 1 provides descriptive statistics for the key variables used in our analysis. Panel A of Table 1 reports the mean of the country-level variables by country. Column 1 shows that the three most (least) corrupt countries with regard to lending are Thailand, Pakistan, and Indonesia (the United Kingdom, Sweden, and Canada), which are is generally consistent with other prior studies (Zheng et al., 2013; Akins, Dou, and Ng, 2017). In terms of economic characteristics, India has the highest economic growth rate of $14 \%$ and Turkey has the highest inflation rate of $33 \%$. The top four countries for GDP per capita are Sweden, the USA, the United Kingdom and Germany. The data on the origin of the company law or commercial code of the country show that nine (twelve, one) are English common (French civil, German civil) law countries. Canada, Sweden, and the United States have the highest rule of law enforcement. Regarding political rights protection, Canada, France, Germany, Italy, Spain, Sweden, USA, and United Kingdom rank higher than other countries. In addition, six countries have relatively higher creditor rights protection than others: Egypt, India, Indonesia, Malaysia, Pakistan, Singapore, and the United 
Kingdom. ${ }^{16}$ The extent of public sector corruption is high in Pakistan, Indonesia, and the Philippines. Regarding the sampling frequency, US firms dominate in our sample, followed by firms in United Kingdom, Canada, France, and Germany. Since the number of observations varies across countries, following Edwards (1992) and Chen et al. (2016), we also employ countryweighted regressions to control for the country representation issue in a robustness check and find that all our results still hold.

Panel B of Table 1 reports the descriptive statistics of bank loan-level variables. The mean (median) value of loan spread is 181 (175) basis points over LIBOR. The average loan amount is 260 million USD and the number of the months to maturity is 48.44 months. $37.8 \%$ of our sample observations have a performance pricing provision, and in terms of loan structure, on average, lead banks hold $25.1 \%$ of the loan. Panel C of Table 1 shows the descriptive statistics of the firm-level variables, which we include as control variables.

Regarding the country-level variables, shown in Panel D of Table 1, the mean of lending corruption is 1.68 , suggesting that on average, firms consider lending corruption to be between "no" and a "minor" obstacle for the operation and growth of their business. Other economic indicators show that the average GDP growth rate and inflation rate are 0.056 and 0.077 , respectively. The mean of the GDP per capita is 14,436.39 USD. Panel D of Table 1 also shows that $39.1 \%$ (52.2\% and 4.4\%) of observations are from English (French, German) legal origin. Finally, the averages of Rule of Law, Political Rights, Creditor Rights, and Public Sector Corruption are $6.467,5.696,2.217$, and -0.518 , respectively.

\footnotetext{
${ }^{16}$ We note that the values for creditor rights in La Porta et al. (1998) are slightly different from those in Djankov, McLiesh, and Shleifer (2007). For example, Egypt's creditor rights value is 4 in La Porta et al. (1998) but 2 in Djankov, McLiesh, and Shleifer (2007). Since our sample is from 1990 through 2009, we choose to use the data version in La Porta et al. (1998), which is roughly in the middle of our sample. Our results are still robust if we use the creditor rights data in Djankov, McLiesh, and Shleifer (2007).
} 


\section{RESULTS}

\subsection{The Effects of Lending Corruption on Bank Loan Contracting - Baseline}

Table 2 reports the estimates of equation (1), where the dependent variables are Ln (Loan Spread) in Column (1), Ln (Loan Size) in Column (2) and Ln (Loan Maturity) in Column (3). In seeking to assess the impact of lending corruption on loan contracting, we focus on the estimated coefficient on Lending Corruption. Column (1) shows that this coefficient is -0.490 ( $t=-5.89)$, indicating that increasing bribes to bank officials reduces the cost of debt. Based on the estimation in Column (1), a one-standard-deviation increase in lending corruption (i.e., the lending corruption index increases by 0.581 ) reduces the cost of debt by more than 59.69 basis points, which is $32.98 \%$ of the sample mean. ${ }^{17}$

Concerning the firm-level control variables (Column 1 of Table 2), leverage is positively related to loan spread, indicating that banks perceive firms with higher leverage as being a higher credit risk. Moreover, firms with larger assets, higher ROA, and a higher tangible assets ratio pay a lower cost of debt. In terms of the country-level control variables, we find that consistent with Bae and Goyal (2009) and Qi, Roth, and Wald (2010), both creditor rights and political rights protection are associated with a lower loan spread. It is worth emphasizing that the coefficient on Public Sector Corruption is positive and significant, suggesting that the cost of debt increases when there is public sector corruption. This result is consistent with that in Qi, Roth, and Wald (2010), who suggest that banks charge higher spreads to cover the cost of potential tunneling (i.e., transfer of assets from borrowers to other parties) facilitated by public sector corruption. Hence, our findings show that after controlling for the effect of general public sector corruption, lending corruption helps reduce lending costs, which is consistent with the "greases the wheels" argument.

\footnotetext{
${ }^{17}$ It was calculated as $\mathrm{e}^{\left(-0.490^{*} 0.581\right)}=(1 / 0.752)-1=32.98 \%$.
} 
In Column (2) of Table 2, the coefficient on Lending Corruption is $0.099(\mathrm{t}=3.59)$, suggesting a positive and significant relationship between lending corruption and Ln (Loan Size). A one-standard-deviation increase in lending corruption increases the loan size by USD 15.37 million, which is $5.91 \%$ of the sample mean. ${ }^{18}$ The results of the control variables suggest that loan size is larger when bank loans have a shorter maturity, when borrowers have a larger firm size and a higher tangibility ratio, and when firms are located in countries with better political rights or creditor rights protection.

Column (3) reports the impact of lending corruption on loan maturity. The estimated coefficient on Lending Corruption is positive and significant $(\mathrm{t}=2.72)$, suggesting that lending corruption is associated with a longer loan maturity. In terms of economic magnitude, a onestandard-deviation increase in lending corruption increases loan maturity by four months, which is $8.33 \%$ of the sample mean. ${ }^{19}$ Clearly, this economic impact is not trivial. Regarding the control variables, loan size is negatively related to loan maturity. Performance pricing, firm size, leverage, ROA, political rights, and creditor rights are positively associated with loan maturity. The results on the control variables are generally in line with findings in the existing bank loan literature (e.g., Qian and Strahan, 2007; Graham, Li, and Qiu, 2008; Bae and Goyal, 2009).

Taken together, our results are consistent with the wealth transfer hypothesis that corruption in the banking sector greases the wheels of business and materially benefits loan borrowers with preferential lending treatment.

\subsection{Endogeneity}

Our baseline empirical results so far show a strong and consistent relationship between lending corruption and loan pricing, loan amount, and loan maturity. However, reverse causality

\footnotetext{
${ }^{18}$ It was calculated as $\mathrm{e}^{\left(0.099^{*} 0.581\right)}-1=\mathrm{e}^{(0.040)}-1=5.91 \%$.

${ }^{19}$ It was calculated as $\mathrm{e}^{(0.138 * 0.581)}-1=\mathrm{e}^{(0.080)}-1=8.33 \%$.
} 
is a potential threat to reliable inferences in our analysis. Although it is not very likely that one firm's loan contract would cause a country's lending corruption level to shift, it may still be plausible that the preferential treatment could encourage bribes and collectively foster the prevalence of corruption in a country. Also, despite including a series of firm, loan, and macroeconomic controls and industry and year fixed effects in the regressions, there are still some concerns about omitted variable bias. If unknown factors (e.g., bank officer characteristics) are correlated with both lending corruption and bank loan contract terms, then our earlier results on the impact of lending corruption will be biased. Although it is extremely difficult to completely eliminate endogeneity bias, in this section, we attempt to address this problem using 1) a difference-in-differences analysis relying on the anti-corruption law reforms that took place in a few countries and 2) an instrumental variables approach.

\subsubsection{Anti-corruption law reforms}

As our first test for endogeneity, we focus on anti-corruption laws passed in 23 countries during our sample period and use them as a natural experiment for implementing the differencein-differences analysis. In particular, we focus on anti-corruption laws that seek to restrain domestic bribery between private parties. If lending corruption reduces borrowing costs and anticorruption laws are instrumental to constraining this type of corruption, then firms in countries where such laws are in force will arguably receive worse loan terms relative to those in countries without similar laws. We therefore use a difference-in-differences framework to study how lending terms change after a country's anti-corruption laws take effect.

To collect the anti-corruption law data, we rely on the 2017 Global Overview of AntiBribery Laws Handbook and examine the anti-corruption laws of the 23 countries in our sample 
from 1995 to $2005 .^{20}$ The handbook documents six legal framework dimensions related to bribery, namely, domestic bribery (private to public), domestic bribery (private to private), the corruption of foreign public officials, facilitation payments, compliance programs, and regulators with the jurisdiction to prosecute corruption. We focus on one of the dimensions, i.e. domestic bribery (private to private), because in this paper we study bribery between two private parties—-borrowers and lenders. Out of the 23 countries in our sample, we identify four anti-corruption legal reforms passed between 1995 and 2005, in Pakistan, Peru, Sweden, and Turkey. For example, in Pakistan, there was a major anti-corruption reform in 1999. This reform, known as the National Accountability Ordinance (NAO), stipulated the corruption and corrupt practices subject to punishment. This ordinance also specified that corruption and corrupt practices would result in a prison term of up to 14 years. $^{21}$

We define an indicator variable, Anti-Corruption Law Reforms, as equal to one if it is within the post-reform period for the four countries and zero otherwise. This variable is also coded as zero for all the other 19 countries. We expect anti-corruption legal reforms to constrain lending corruption and to lead to more stringent loan terms. Regarding the model specification, we replace Lending Corruption from our baseline model with Anti-Corruption Law Reforms. We control for firm fixed effects that effectively condition out all the time-invariant firm characteristics that may contribute to loan costs. Table 3 reports the estimation results. We find that the coefficients of Anti-Corruption Law Reforms are significantly positive on loan spread (Column 1) and significantly negative on loan maturity (Column 3), indicating that after anti-corruption legal reforms, the loan spread increases and loan maturity decreases. This result corroborates our

\footnotetext{
${ }^{20}$ The data are also available on this website: https://globalcompliancenews.com/anti-corruption/anti-corruptionlaws-around-the-world/. The database provides the anti-corruption legal framework for 46 jurisdictions regulating domestic bribery across both developed and developing countries.

${ }^{21}$ More details of the NAO can be found here: http://www.nab.gov.pk/Downloads/nao.asp\#Corruption_12.
} 
previous findings that higher lending corruption is associated with more favorable loan contract terms.

\subsubsection{Instrumental variables analysis}

In our second attempt to address potential endogeneity problems, we use the instrumental variable (IV) estimation method. The underlying assumption on these instrumental variables is that they are highly correlated with lending corruption but they (arguably) do not directly affect bank loan contracting terms, except through the lending corruption channel (Adams and Ferreira, 2009). Similar to prior papers that investigate the effect of cross-country characteristics (e.g., Beck, Demirguc-Kunt, and Levine, 2006; Barth et al., 2009; Houston, Lin, and Ma, 2011), we consider multiple country-level variables used in the prior literature that are reasonably exogenous to loan contracting terms and that are likely to have explanatory power for lending corruption. ${ }^{22}$

Our first instrument of lending corruption is State Media Ownership, which is measured by the market share of state-owned newspapers out of the aggregate market share of the five largest daily newspapers (by circulation) (Djankov et al., 2003). Houston, Lin, and Ma (2011) show that greater media concentration and state ownership of the media increases the odds of lending corruption. It is unlikely that media concentration affects the terms of individual loan contracts.

Following prior literature (e.g., Beck et al, 2003, 2006; Barth et al., 2009; Houston, Lin, and Ma, 2011), we also search for potential instrumental variables for a culture of lending corruption based on the endowment theory. Under this theory, the geographic environment plays a role in shaping institutional development. In line with the prior literature, we consider three

\footnotetext{
${ }^{22}$ Similar to these papers, we do not claim that these variables are the best instrument variables. Instead, we are looking for reasonable instrumental variables that prior literature does not document as having a direct effect on loan contracting terms (Adams and Ferreira, 2009).
} 
measures as instrumental variables: latitude (Latitude), ethnic fractionalization (Ethnic Fractionalization), and independent history (Independent History).

Latitude refers to the country-level absolute value of the latitude (La Porta et al., 1999). An extensive literature has established that a country's absolute value latitude is positively associated with the quality of its political institutions (e.g., Treisman, 2000; Acemoglu, Johnson, and Robinson, 2001), which, in turn, should reduce lending corruption. Ethnic Fractionalization is the probability of two randomly selected persons not speaking the same language in a country. Prior studies find that economies with greater ethnic diversity demonstrate a preference for institutions that facilitate expropriation (Easterly and Levine, 1997; Beck, Demirguc-Kunt, and Levine 2003, 2006). Hence, we expect a positive association between ethnic fractionalization and lending corruption. Independent History refers to the percentage of years that the country has been independent since 1776. Prior literature has argued that countries that gained independence earlier have had a greater chance to modify colonial institutions and adopt policies that are more conducive to economic growth (Beck, Demirguc-Kunt, and Levine 2003, 2006). In line with this argument, we expect a positive association between independent history and lending corruption.

We apply a two-stage least square (2SLS) estimation in the IV approach. In the first stage, we use Lending Corruption as the dependent variable and State Media Ownership, Latitude, Ethnic Fractionalization, and Independent History as the instrumental variables. Consistent with expectations and prior studies, the results in the first stage regression indicate that lending corruption is positively related to State Media Ownership, Ethnic Fractionalization, and Independent History and negatively related to Latitude..$^{23}$ The coefficients on these instrumental

\footnotetext{
${ }^{23}$ Following prior studies, for parsimony we do not tabulate the $1^{\text {st }}$ stage results. These results are available upon request.
} 
variables are statistically significant at the $1 \%$ level. In addition, the null hypothesis that the instruments are weak is rejected at the $5 \%$ level. ${ }^{24}$

Table 4 reports the second-stage regression results. The coefficients on Lending Corruption are negative on loan cost (Column (1)) $(\beta=-0.213 ; \mathrm{t}=-1.84)$ and positive on loan amount and maturity (Columns (2) and (3)) $(\beta=0.095,0.208 ; \mathrm{t}=3.45,3.25)$. Overall, our IV estimation is highly consistent with our baseline model, reinforcing our findings that in high lending corruption countries, borrowers enjoy favorable loan contract terms.

\subsection{Cross-Sectional Tests}

\subsubsection{The effect of financial distress}

Firms with financial distress face difficulties in getting financing from either equity or debt markets (Altman, 1984; Lang and Stulz, 1992). Since it is hard for distressed firms to finance through regular channels, they have an incentive to bribe lenders in order to solicit funding and the expected benefits of such bribery is likely to be greater for these borrowers. We therefore expect to find that the effects of lending corruption on bank loan contracting is more pronounced for distressed firms.

To test this conjecture, we include the proxy for borrowers' financial distress and its interaction with Lending Corruption (i.e., Financial Distress *Lending Corruption) in the baseline model (1). In particular, we measure firms' Financial Distress using (-1)*Z-Score (Altman, 1968; 2000). Panel A of Table 5 reports the results with dependent variables Ln (Loan Spread) in Column (1), Ln (Loan Size) in Column (2), and Ln (Loan Maturity) in Column (3). In the rest of the three panels of Table 5, we also present the results using the same dependent variables in the same order.

\footnotetext{
${ }^{24}$ We employ the weak instrument test (Olea and Pflueger, 2013), where the null hypothesis is that the estimator approximate asymptotic bias or the instruments are weak. The F-values are 264.15, 493.03, and 493.28 in each of the three models.
} 
The coefficient on Financial Distress is positive in Column (1) and negative in Column (2), respectively, indicating that banks view distressed firms as riskier and thus charge them a higher spread and lend to them less. More importantly, the coefficient on Lending Corruption*Financial Distress in Column (2) (Column (3)) is positive and significant at 5\% level, suggesting that the negative (positive) effects of lending corruption on loan size (loan maturity) are strengthened for distressed firms. We do not find significant results for loan spreads in Column (1). However, in general, the results in Panel A of Table 5 suggest that the effects of lending corruption on bank loan contracting (in terms of spread and loan size) are more pronounced for distressed firms.

\subsubsection{The effect of foreign banks}

A strand of the banking literature investigates the effect of foreign banks' entry on the host country's banks. Previous studies document that foreign banks increase market competition, improve the efficiency of domestic banks, and that they have much sounder financial profiles and a superior ability to monitor borrowers than do local banks (Unite and Sullivan, 2003; Detragiache, Tressel, and Gupta, 2008; Bruno and Hauswald, 2014). Following the existing literature, an increase in foreign ownership within the banking industry could improve operating efficiency and increase monitoring effectively and is expected to mitigate lending corruption's impact on bank loan cost reduction.

To test this hypothesis, we include Foreign Ownership, measured as the share of banks majority-owned by foreigners and its interaction with Lending Corruption (i.e., Foreign Ownership * Lending Corruption) into our baseline model. Panel B of Table 5 reports the results. In Column (1), the coefficient on Lending Corruption*Foreign Ownership is positive and significant, indicating that the effects of lending corruption on bank loan spread is less pronounced in countries with a higher foreign ownership in banks. The results suggest that foreign ownership 
plays an important monitoring role in bank practices, making the relationship between lending corruption and the cost of debt weaker. In line with the effect on loan spread, the coefficient of the interaction term Lending Corruption* Foreign Ownership on loan size is positive and significant, as shown in Column (2), suggesting that the effects of lending corruption on loan size are less pronounced in countries with higher foreign ownership in banks. We do not find a significant effect on loan maturity in Column (3). In summary, Panel B of Table 5 shows that in countries with greater foreign ownership in banks, the effects of lending corruption on extending preferential bank loan terms (including loan spread and loan size) become weaker.

\subsubsection{The effect of religion}

As new institutional economics theory suggests, social embeddedness, including religion and norms, plays an important role in explaining social behaviors. Using the World Value Survey (WVS), Chen et al. (2016) find that country-level religion significantly influences bank loan contracting. More specifically, they find that firms in stronger religiosity countries have a lower cost of debt, a larger loan size, and lower upfront fees. They argue that managers in stronger religiosity environments are inclined to maintain higher ethical standards and are less likely to engage in risk-taking behaviors. Treisman (2000) systematically investigates the causes of corruption. He points out that compared to Catholicism, Eastern Orthodoxy, and Islam, Protestantism can significantly constrain corruption. The reason he gives is that the Protestant tradition can effectively monitor the government and other parties in the society. This result is also in line with La Porta et al. (1999), who show that Protestant countries are more likely to have a developed economy and a higher quality government.

In this cross-sectional test, we add a proxy for a country's religion, Protestant, and its interaction with Lending Corruption. Protestant equals one if the primary religion of the country 
is Protestantism, zero otherwise. As shown in Panel C of Table 5, Protestant is negatively correlated with loan spread and positively associated with loan maturity and loan size. In addition, the coefficient on Lending Corruption* Protestant is positive and significant at $1 \%$ level in Column (1), indicating that a Protestant tradition weakens the relationship between lending corruption and bank loan spread. In Column (2) and (3), we find that the coefficient on this interaction term is negative and significant at 5\% level, suggesting that the relationship between lending corruption and loan size (loan maturity) is weaker in Protestant countries. Overall, our findings imply that the effects of lending corruption on bank loan contracting (in terms of loan spread and maturity) are weaker in Protestant countries.

\subsection{Lending Corruption and Loan Syndication}

In this section, we analyze the relationship between lending corruption and the loan structure, i.e., the loan allocation to lead banks among syndicated loans. The lead bank's officials are typically those who interact with and work out the arrangements for a syndicated loan. Hence, information asymmetry exists between the lead bank and the participant banks (Sufi, 2007). In a society with high levels of lending corruption, participant banks, faced with information asymmetry, are more likely to be concerned about whether a syndicated loan is tainted by bribery of the lead bank's officials. In other words, the risk of losses due to adverse selection is greater for participant banks when there are corruption-related agency problems at the lead bank. Therefore, one might expect participant banks to either not participate in syndicated lending or to lend out less in countries where lending corruption is more prevalent.

Table 6 reports the results of lending corruption on syndicate structure. In Column (1), the dependent variable is Syndicated Loan, an indicator of whether or not a loan is syndicated. We perform a logit regression and find that Lending Corruption is negative and significant $(\beta=-1.565$; 
$\mathrm{z}=-6.34$ ), suggesting that in countries with greater lending corruption, the likelihood of forming a syndicate is lower. Column (2) shows the results of the Poisson regression with Number of Lenders (i.e., the number of lenders in the syndicated loan) as the dependent variable. The coefficient on Lending Corruption is negative and significant $(\beta=-0.176 ; \mathrm{z}=-2.87)$, suggesting that in higher lending corruption countries, fewer lenders are willing to participate in syndicated loans. In Column (3), we investigate the effects of lending corruption on the lead bank allocation in syndicated loans. The dependent variable Lead Bank Allocation is defined as the percentage of loans that are lent out by lead banks. The coefficient on Lending Corruption is positive and significant $(\beta=0.108 ; \mathrm{t}=3.79)$, indicating that in a corrupted lending environment, lead banks tend to hold a higher loan amount than do other banks.

\subsection{Lending Corruption, Leverage Policy, and Debt Choice}

Next, we examine firms' response to lending corruption. More specifically, we test the impact of lending corruption on borrowers' leverage policies and their debt choices. Table 7 reports the results of lending corruption on leverage policy, where we use Leverage (Column (1)), Short-term Leverage (Column (2)), and Long-term Leverage (Column (3)) to capture borrowers' leverage policies. Column (1) in Table 7 shows a positive relationship between Lending Corruption and the leverage ratio, suggesting that in countries with a higher level of lending corruption, firms are inclined to have a higher leverage ratio. In the next step, we explore which type of leverage (short vs. long term) increases with lending corruption. The results in Columns (2) and (3) suggest that lending corruption is positively associated with the long-term, but not short-term, leverage ratio. This is consistent with the finding in Column (3) of Table 2 that loan maturity is longer in high lending corruption countries. 
Our analysis establishes that higher lending corruption leads to more favorable loan terms. A natural question to ask is whether borrowers take advantage of this corruption and increase financing through bank loans, as opposed to public debt. We thus examine the relationship between lending corruption and debt choice with debt structure data from Capital IQ. ${ }^{25}$

As reported in Column (1) of Table 8, we regress the bank debt ratio on lending corruption. Bank Debt Ratio is defined as the summation of term loans and revolving credit scaled by total firm debt. The coefficient on Lending Corruption is positive and significant $(\mathrm{t}=5.91)$, suggesting that in a corrupt lending environment, companies are more likely to finance through bank debt. In comparison, in Column (2), we investigate the impact of Lending Corruption on Public Debt Ratio, defined as the sum of senior bonds and notes, subordinated bonds and notes, and commercial paper, scaled by total debt. As expected, we find that the coefficient on Lending Corruption is negative and significant $(\mathrm{t}=-3.24)$, indicating that companies in higher lending corruption countries are less likely to issue public debt.

\subsection{Lending Corruption, Loan Quality, Bank Performance, and Troubled Banks during the}

\section{Financial Crisis}

In this section, we investigate the outcome of lending corruption by studying bank performance, loan quality, and the exposure of the banks to financial trouble during periods of financial crisis. With bribed bank officers making loan decisions, it is not surprising that banks face a significant risk of making loans with terms that are detrimental to the interests of the banks. In other words, lending corruption could result in an agency problem in loan contracting that eventually endangers banks.

\footnotetext{
${ }^{25}$ Previous literature widely uses this database to examine the determinants of debt choice (e.g., Lin et al., 2013; Lin, 2015).
} 
In Table 9, we examine the impact of lending corruption on loan quality and bank performance. If lending corruption results in banks providing loans to unqualified borrowers, we expect those loans to be riskier and more likely to become non performing. To test this hypothesis, we regress loan quality measures on lending corruption. We use Bank NPL and Bank LLR to proxy for loan quality, where Bank NPL is non-performing loans scaled by gross loans, and Bank LLR is loan loss reserves scaled by gross loans. Columns (1) and (2) of Table 9 show that Lending Corruption is positive and significant in both regressions ( $\mathrm{t}=2.49$ and 6.43$)$, indicating that loan quality is worse in countries with greater lending corruption. We measure bank performance by Bank ROA, that is, earnings before taxes and loan loss provisions divided by total assets. Column (3) of Table 9 shows that lending corruption is negatively correlated with Bank ROA, suggesting that bank performance is adversely affected by lending corruption.

Next, we examine whether lending corruption is related to banks' financial trouble during the 2007-2009 financial crisis. Following Beltratti and Stulz (2012) and Kanagaretnam et al. (2018), Bank Trouble is defined as an indicator that is equal to one if a bank was in financial trouble during the crisis period of 2007-2009, zero otherwise. A bank is considered in financial trouble in 2007-2009 if it satisfies at least one of the following criteria: (1) ROA $<-2 \%$, equity/assets $<0.06$, and (3) loan loss provisions/total loans $>0.01$. To ensure that these banks were not troubled before 2007, banks that satisfy any of the above criteria in 2006 are deleted from the sample. Therefore, in this analysis, we only consider banks that were financially healthy in 2006 but became troubled in 2007-2009. Meanwhile, we also control for bank-level and countrylevel variables. These variables include: Bank Size, the natural logarithm of total assets; Bank Growth, the growth rate in net interest revenue; Bank Equity, equity divided by total assets; Bank Big, an indicator that the bank is too big to fail, which equals one if the bank's share of the 
country's total deposits is more than $10 \%$ and zero otherwise; Bank State-owned, an indicator that equals one if the bank is state owned, zero otherwise; Bank Listed, which equals one if the bank is listed and zero otherwise; Bank IFRS, which equals one if the bank adopts IFRS during the year and zero otherwise.

Table 10 reports the results of lending corruption on the probability of banks entering financial trouble. As shown, the coefficient on Lending Corruption is positive and significant $\left(\beta_{1}=0.834, \mathrm{z}=2.07\right)$, indicating that banks in higher lending corruption countries were more likely to get into financial trouble during the crisis period. In summary, our findings in this section reinforce the wealth transfer hypothesis that banks, as the losing principal, are more likely to suffer in countries with greater lending corruption as they end up with poorer loan quality, a worse earnings performance, and a higher chance of getting into trouble during a financial crisis.

\section{SENSITIVITY ANALYSES}

To test the robustness of our main results, we also conduct a series of sensitivity analyses. First, since our sample is dominated by bank loans originated in the U.S., our results may be driven by bribery in the U.S. banking sector. To mitigate this concern, we repeat our analysis by dropping U.S. bank loans from the sample. Table 11 shows that our main results still hold. In addition, we also follow Edwards (1992) and Chen et al. (2016) and employ country-weighted regressions to address the country representation issue and find that the results are still robust. Second, Chen et al. (2016) find that firms located in areas with a higher level of religiosity receive more favorable bank loan terms. To mitigate the potential omitted variable issue, we also control for the countrylevel degree of religiosity in our main regressions, where religiosity is measured as the principal component factor derived from the three religion variables: Member of religion, Religion 
important, and Religion services, as in Chen et al. (2016). ${ }^{26} \mathrm{We}$ find that our results do not alter. Third, we repeat our main analyses while clustering standard errors by countries and find our results are robust. Fourth, although it is reasonable to assume that corruption in one country's banking sector is not easy to change quickly, one might still worry about the length of the sample period. We change the sample interval from 10 to 20 years. More specifically, we extend the sample to the years between 1990 and 2010 and we find our results are still robust.

\section{CONCLUSION}

Lending corruption is a critical issue. Prior literature mainly focuses on its determinants, with only limited research documenting its consequences. In this paper, we examine how lending corruption affects bank loan contracting. Specifically, we empirically examine how lending costs are affected by lending corruption across twenty-three different countries. In addition to the cost of bank loans, we also examine the non-pricing terms of loan contracts, including loan maturity and loan amount. We find that lending corruption helps reduce the cost of bank loans and is associated with a longer loan maturity and larger loan amounts. Next, we examine cross-sectional variation and find that the lending corruption effect is stronger when firms are under more financing constraints, and weaker in countries with higher foreign ownership of banks or where the primary religion is Protestant. Third, in the syndicated loan market, participant banks are inclined to lend out less in countries with where lending corruption is more prevalent. Fourth, we study to what extent lending corruption impacts the likelihood that firms choose bank loans versus public bonds. We find that corruption in bank lending serves to "grease the wheels" of borrowing

\footnotetext{
${ }^{26}$ All those three country-level variables are from World Value Survey (WVS). Member of religion, Religion important and Religion services capture 1) The proportion of respondents who indicate they are affiliated with a religion based on the WVS. 2) The proportion of respondents who indicate the religion is important to themselves based on the WVS. 3) The proportion of respondents who indicate they attend religious services more than once a year based on the WVS.
} 
from banks, with borrowers increasingly opting for private loans over public debt. Finally, we extend our analysis by investigating how lending corruption affects loan quality and bank financial health. We find that as lending corruption increases, both loan quality and bank financial health deteriorates. Our findings suggest that although borrowers may benefit from lending corruption (as do corrupted bank officials), banks are adversely impacted, which eventually harms bank shareholders. 


\section{References}

Acemoglu, D., Johnson, S., Robinson, J.A., 2001. The colonial origins of comparative development: An empirical investigation. American Economic Review 91, pp.1369-1401.

Adams, R.B., and Ferreira, D., 2009. Women in the boardroom and their impact on governance and performance. Journal of Financial Economics 94(2), pp.291-309.

Aidt, T.S., 2003. Economic analysis of corruption: a survey. The Economic Journal 113(491), 632-652.

Aidt, T.S., 2009. Corruption, institutions, and economic development. Oxford Review of Economic Policy 25(2), 271-291.

Akins, B., Dou, Y., and Ng, J., 2017. Corruption in bank lending: The role of timely loan loss recognition. Journal of Accounting and Economics 63(2-3), pp.454-478.

Altman, E.I., 1968. Financial ratios, discriminant analysis and the prediction of corporate bankruptcy. Journal of Finance 23(4), pp.589-609.

Altman, E.I., 1984. A further empirical investigation of the bankruptcy cost question. Journal of Finance 39(4), pp.1067-1089.

Altman, E.I., 2000. Predicting financial distress of companies: Revisiting the Z-score and ZETA models. Stern School of Business, New York University, 9-12.

Bae, K.H., and Goyal, V.K., 2009. Creditor rights, enforcement, and bank loans. The Journal of Finance 64(2), pp.823-860.

Bandyopadhyay, Y., 2016. How corrupt are our bankers?

https://www.livemint.com/Opinion/uG17NBV5ePFHffisBJOTjL/How-corrupt-are-ourbankers.html

Bardhan, P., 1997. Corruption and development: a review of issues. Journal of Economic Literature 35(3), pp.1320-1346.

Barth, J.R., Caprio, G., and Levine, R., 2006. Rethinking bank regulation. Till Angels Govern. Cambridge University Press 2006

Barth, J.R., Lin, C., Lin, P., and Song, F.M., 2009. Corruption in bank lending to firms: Crosscountry micro evidence on the beneficial role of competition and information sharing. Journal of Financial Economics 91(3), pp.361-388.

Beck, T., Demirgüç-Kunt, A., and Levine, R., 2003. Law, endowments, and finance. Journal of Financial Economics 70(2), pp.137-181. 
Beck, T., Demirguc-Kunt, A., Levine, R., 2006. Bank supervision and corruption in lending. Journal of Monetary Economics 53, 2131-2163.

Beltratti, A., and Stulz, R.M., 2012. The credit crisis around the globe: Why did some banks perform better? Journal of Financial Economics 105(1), pp.1-17.

Bhargava, V.K., and Bolongaita, E.P., 2004. Challenging Corruption in Asia: Case studies and a framework for action. World Bank Publications.

Bruno, V., and Hauswald, R., 2014. The real effect of foreign banks. Review of Finance 18(5), pp.1683-1716.

Chava, S., and Roberts, M.R., 2008. How does financing impact investment? The role of debt covenants. Journal of Finance 63(5), pp.2085-2121.

Chen, H., Huang, H.H., Lobo, G.J., and Wang, C., 2016. Religiosity and the cost of debt. Journal of Banking and Finance 70, pp.70-85.

Dass, N., Nanda, V.K., and Xiao, S.C., 2017. Is There a Local Culture of Corruption in the US? SSRN Working paper.

Demirgüç-Kunt, A., Feyen, E., and Levine, R., 2013. The evolving importance of banks and securities markets. The World Bank Economic Review 27(3), pp.476-490.

Detragiache, E., Tressel, T., and Gupta, P., 2008. Foreign banks in poor countries: theory and evidence. Journal of Finance 63(5), pp.2123-2160.

Diamond, D.W., and Dybvig, P.H., 1983. Bank runs, deposit insurance, and liquidity. Journal of Political Economy 91(3), pp.401-419.

Djankov, S., McLiesh, C., Nenova, T., and Shleifer, A., 2003. Who owns the media? Journal of Law and Economics 46(2), pp.341-382.

Djankov, S., McLiesh, C., and Shleifer, A., 2007. Private credit in 129 countries. Journal of Financial Economics 84(2), 299-329.

Donadelli, M., Fasan, M., and Magnanelli, B.S., 2014. The agency problem, financial performance and corruption: Country, industry and firm level perspectives. European Management Review 11(3-4), pp.259-272.

Duchin, R., 2010. Cash holdings and corporate diversification. The Journal of Finance 65(3), 955992.

Easterly, W. and Levine, R., 1997. Africa's growth tragedy: policies and ethnic divisions. The Quarterly Journal of Economics, 112(4), pp.1203-1250. 
Edwards, S., 1992. Trade orientation, distortions, and growth in developing countries. Journal of Development Economics 39(1), pp.31-57.

Ehrlich, I., and Lui, F.T., 1999. Bureaucratic corruption and endogenous economic growth. Journal of Political Economy 107(S6), pp.270-293.

Favara, G., Schroth, E., and Valta, P., 2012. Strategic default and equity risk across countries. Journal of Finance 67(6), pp.2051-2095.

Favara, G., Morellec, E., Schroth, E., and Valta, P., 2017. Debt enforcement, investment, and risktaking across countries. Journal of Financial Economics 123(1), pp.22-41.

Fernández, R., 2011. Does culture matter? In Handbook of social economics (Vol. 1, pp. 481-510). North-Holland.

Giannetti, M., and Yafeh, Y., 2012. Do cultural differences between contracting parties matter? Evidence from syndicated bank loans. Management Science 58(2), pp.365-383.

Gorton, G., and Huang, L., 2004. Liquidity, efficiency, and bank bailouts. American Economic Review 94(3), pp.455-483.

Graham, J.R., Li, S., and Qiu, J., 2008. Corporate misreporting and bank loan contracting. Journal of Financial Economics 89(1), pp.44-61.

Groenendijk, N., 1997. A principal-agent model of corruption. Crime, Law and Social Change 27(3-4), pp.207-229.

Guiso, L., Sapienza, P., and Zingales, L., 2004. Does local financial development matter? Quarterly Journal of Economics 119, 929-969.

Houston, J.F., Lin, C., and Ma, Y., 2011. Media ownership, concentration and corruption in bank lending. Journal of Financial Economics 100(2), 326-350.

Houston, J.F., Jiang, L., Lin, C., and Ma, Y., 2014. Political connections and the cost of bank loans. Journal of Accounting Research 52(1), pp.193-243.

Huntington, S.P., 2002. Modernization and corruption. Political Corruption: Concepts and Contexts, pp.253-263.

Jensen, M.C., and Meckling, W.H., 1976. Theory of the firm: Managerial behavior, agency costs and ownership structure. Journal of Financial Economics 3(4), pp.305-360.

Kanagaretnam, K, Lobo, G. J., Wang, C., and Whalen, D. J., 2018. Cross-country Evidence on the Relation between Societal Trust and Risk-Taking by Banks. Journal of Financial and Quantitative Analysis. Forthcoming. 
Khwaja, A.I., and Mian, A., 2005. Do lenders favor politically connected firms? Rent provision in an emerging financial market. The Quarterly Journal of Economics 120(4), pp.1371-1411.

Kim, J-B., Tsui, J.S.L., and Yi, C.H., 2011. The voluntary adoption of International Financial Reporting Standards and loan contracting around the world. Review of Accounting Studies 16(4), pp.779-811.

King, R.G., Levine, R., 1993. Finance and growth: Schumpeter might be right. Quarterly Journal of Economics 108, 717-737.

Lang, L.H.P., and Stulz, R., 1992. Contagion and competitive intra-industry effects of bankruptcy announcements: An empirical analysis. Journal of Financial Economics 32(1), pp.45-60.

La Porta, R., Lopez-de-Silanes, F., Shleifer, A., and Vishny, R.W., 1998. Law and finance. Journal of Political Economy 106(6), 1113-1155.

La Porta, R., Lopez-de-Silanes, F., Shleifer, A., and Vishny, R., 1999. The quality of government. The Journal of Law, Economics, and Organization 15(1), pp.222-279.

Leff, N.H., 1964. Economic development through bureaucratic corruption. American Behavioral Scientist 8(3), pp.8-14.

Levin, M., and Satarov, G., 2000. Corruption and institutions in Russia. European Journal of Political Economy 16(1), pp.113-132.

Levine, R., 2005. Finance and growth: Theory and evidence. In: Aghion, P., Durlauf, S. (Eds.), Handbook of Economic Growth. North-Holland Elsevier Publishers, Amsterdam.

Leys, C., 1965. What is the Problem about Corruption? The Journal of Modern African Studies 3(2), pp.215-230.

Lin, C., Ma, Y., Malatesta, P., and Xuan, Y., 2013. Corporate ownership structure and the choice between bank debt and public debt. Journal of Financial Economics 109 (2), 517-534.

Lin, L., 2016. Collateral and the choice between bank debt and public debt. Management Science 62(1), pp.111-127.

Liu, X., 2016. Corruption culture and corporate misconduct. Journal of Financial Economics 122(2), pp.307-327.

Lui, F.T., 1985. An equilibrium queuing model of bribery. Journal of Political Economy 93(4), pp.760-781.

Mauro, P., 1995. Corruption and growth. The Quarterly Journal of Economics 110(3), pp.681-712. 
Meon, P-G., and Weill, L., 2010. Is corruption an efficient grease? World Development 38(3), pp.244-259.

Mo, P.H., 2001. Corruption and economic growth. Journal of Comparative Economics 29(1), pp.66-79.

Murphy, K.M., Shleifer, A., and Vishny, R.W., 1993. Why is rent-seeking so costly to growth? The American Economic Review 83(2), pp.409-414.

New York Times, 2015. Wells Fargo and JPMorgan Loan Officers Accused of Taking Kickbacks. https://dealbook.nytimes.com/2015/01/22/wells-fargo-and-jpmorgan-loan-officers-accused-oftaking-kickbacks/

Olea, J.L.M., and Pflueger, C., 2013. A robust test for weak instruments. Journal of Business \& Economic Statistics 31(3), pp.358-369.

Pacini, C., Swingen, J.A., and Rogers, H., 2002. The role of the OECD and EU Conventions in combating bribery of foreign public officials. Journal of Business Ethics 37(4), pp.385-405.

Park, J., 2012. Corruption, soundness of the banking sector, and economic growth: A cross-country study. Journal of International Money and Finance 31(5), pp.907-929.

Qi, Y., Roth, L., and Wald, J.K., 2010. Political rights and the cost of debt. Journal of Financial Economics 95, 202-226.

Qian, J., and Strahan, P.E., 2007. How laws and institutions shape financial contracts: The case of bank loans. Journal of Finance 62(6), 2803-2834.

Rajan, R.G., and Zingales, L., 1998. Financial dependence and growth. American Economic Review 88, 559-586.

Ratley, J.D., 2014. Global Fraud Study-Report to The Nations on Occupational Fraud and Abuse. https://www.acfe.com/rttn/docs/2014-report-to-nations.pdf.

Shleifer, A., and Vishny, R.W., 1993. Corruption. The Quarterly Journal of Economics 108(3), pp.599-617.

Smith, J.D., 2016. US political corruption and firm financial policies. Journal of Financial Economics, 121(2), pp.350-367.

Sufi, A., 2007. Information Asymmetry and Financing Arrangements: Evidence from Syndicated Loans. Journal of Finance 62, 629-668.

Tanzi, V., 1998. Corruption around the world: Causes, consequences, scope, and cures. Staff Papers 45(4), pp.559-594. 
The New York Times, 2015. Wells Fargo and JPMorgan Loan Officers Accused of Taking Kickbacks. https://dealbook.nytimes.com/2015/01/22/wells-fargo-and-jpmorgan-loan-officersaccused-of-taking-kickbacks/

Treisman, D., 2000. The causes of corruption: a cross-national study. Journal of Public Economics 76(3), pp.399-457.

Unite, A.A., and Sullivan, M.J., 2003. The effect of foreign entry and ownership structure on the Philippine domestic banking market. Journal of Banking \& Finance 27(12), pp.2323-2345.

Wei, S.J., 2000. How taxing is corruption on international investors? Review of Economics and Statistics 82(1), pp.1-11.

Weill, L., 2011. How corruption affects bank lending in Russia. Economic Systems 35(2), pp.230243.

World Bank, 2000.World Business Environment Survey. The World Bank, Washington, DC.

Zheng, X., El Ghoul, S., Guedhami, O., and Kwok, C.C.Y., 2013. Collectivism and corruption in bank lending. Journal of International Business Studies, 44(4), pp.363-390. 
Appendix A

\begin{tabular}{ll}
\hline Variable name & Variable definitions and constructions \\
\hline $\begin{array}{l}\text { Lending Corruption Variable } \\
\text { Lending Corruption }\end{array}$ & $\begin{array}{l}\text { Country-level average of the firm response to the question, "Is the } \\
\text { corruption of bank officials an obstacle for the operation and growth of your } \\
\text { business?" (1, no obstacle; 2, minor obstacle; } 3 \text {, moderate obstacle; 4, major } \\
\text { obstacle). Source: World Business Environment Survey (World Bank, } \\
\text { 2000). }\end{array}$ \\
$\begin{array}{l}\text { Anti-Corruption Law } \\
\text { Reforms }\end{array}$ & $\begin{array}{l}\text { Indicator variable that equals } 1 \text { for the observations in Pakistan, Peru, } \\
\text { Sweden, and Turkey during the post-reform period, 0 otherwise. }\end{array}$
\end{tabular}

Bank Loan Variables

Spread

Ln (Spread)

Loan Size

Ln (Loan Size)

Loan Maturity

Ln (Loan Maturity)

Secured

Performance Pricing

Syndicated Loan

Number of Lenders

Lead Bank Allocation

Firm-level Variables

Ln (Firm Size)

Tangibility

Leverage

$R O A$

Tobin $Q$

Prob. Bankruptcy
The amount the borrower pays in basis points over LIBOR for each dollar drawn down. Source: DealScan.

Natural logarithm of the amount the borrower pays in basis points over LIBOR for each dollar drawn down. Source: DealScan.

The USD loan amount of the facility in billions. Source: DealScan.

Natural logarithm of the USD loan amount of the facility in billions. Source: DealScan.

The number of the months to maturity. Source: DealScan.

Natural logarithm of the number of the months to maturity. Source: DealScan.

Indicator variable that equals 1 if the loan involves collateral, 0 otherwise. Source: DealScan.

Indicator variable that equals 1 if the loan includes a performance pricing provision, 0 otherwise. Source: DealScan.

Indicator variable that equals 1 if the loan is syndicated, 0 otherwise. Source: DealScan.

Number of lenders in the bank loan. Source: DealScan.

Percentage of loan held by the lead bank. Source: DealScan.

Natural logarithm of total assets. Source: Compustat Global.

Gross property, plant, and equipment scaled by total assets. Source: Compustat Global.

Current and long-term debt scaled by total assets. Source: Compustat Global.

Pre-tax income scaled by total assets. Source: Compustat Global.

Following Duchin's (2010) definition:

$\mathrm{Q}=$ market value of assets $/(0.9 *$ book value of assets $+0.1 *$ market value of assets), where the market value of assets is the book value of total assets (AT) less the book value of equity (CEQ) less deferred taxes (TXTDB) plus the market value of equity (CSHO * PRCC). Source: Compustat Global. The probability of bankruptcy, using scores based on Altman (2000). 


\begin{tabular}{ll}
\hline $\begin{array}{l}\text { Country Variables } \\
\text { Economic Growth }\end{array}$ & $\begin{array}{l}\text { GDP growth rate (US dollars, current prices). Source: International } \\
\text { Monetary Fund. } \\
\text { Inflation }\end{array}$ \\
Inflation rate percentage. Source: International Monetary Fund. \\
Natural logarithm of gross domestic product per capita (US dollars, current \\
prices). Source: International Monetary Fund. \\
English Law \\
Indicator variable that equals 1 if the legal origin is English law, zero \\
otherwise. Source: La Porta et al. (1998).
\end{tabular}

Debt Choice Variables

Bank Debt Ratio

Bank debt scaled by total debt. Bank debt is defined as the sum of term loans and revolving credit. Source: Capital IQ.

Public Debt Ratio $\quad$ Public debt scaled by total debt. Public debt is defined as the sum of senior bonds and notes, subordinated bonds and notes, and commercial paper. Source: Capital IQ.

Leverage Policy Variables

Short-term Leverage Current debt scaled by total assets. Source: Compustat Global.

Long-term Leverage Long-term debt scaled by total assets. Source: Compustat Global.

\section{Bank-level Test Variables}

Bank ROA Earnings before taxes and loan loss provisions divided by assets. Source: BankScope.

Bank NPL Non-performance loan scaled by gross loans. Source: BankScope.

Bank LLR

Bank Trouble Loan loss reserves scaled by gross loans. Source: BankScope.

$=1$ if the bank is in financial trouble during the crisis period 2007-2009, $=0$ if otherwise. A troubled bank is defined as a bank that satisfies at least one of the following criteria in 2007-2009:

(1)ROA $<-2 \%$, (2) equity/assets $<0.06$, and (3) loan loss provisions/total loans $>0.01$. To ensure that these banks were not troubled before 2007, banks that satisfy any of the above criteria in 2006 are deleted from the 
Bank Size

Bank Growth

Bank Equity

Bank Big

Bank State-owned

Bank Listed

Bank IFRS

\section{Instrumental Variables}

State Media Ownership

Latitude

Ethnic Fractionalization

Independent History

Cross-sectional Variables

Financial Distress

Foreign Ownership

Protestant

Fixed Effect Variables

Industry

Year

Loan Purposes

Loan Types sample. Thus, the sample banks used in the tests include only those that were healthy in 2006 but troubled in 2007-2009. Source: BankScope.

Natural logarithm of total assets. Source: BankScope.

Growth in net interest revenue. Source: BankScope.

Equity divided by total assets. Source: BankScope.

An indicator that the bank is too big to fail. It equals 1 if the bank's share of the country's total deposits is more than $10 \%, 0$ otherwise. Source:

BankScope.

Indicator variable that equals 1 if the bank is state-owned, 0 otherwise.

Source: BankScope.

Indicator variable that equals 1 if the bank is listed, 0 otherwise. Source:

BankScope.

Indicator variable that equals 1 if the bank adopts IFRS during the year, 0 otherwise. Source: BankScope.

The market share of state-owned newspapers out of the aggregate market share of the five largest daily newspapers (by circulation). Source: Djankov et al. (2003).

The country-level absolute value of the latitude from La Porta et al. (1999).

Source: La Porta et al. (1999) and Beck, Demirgüç-Kunt, and Levine (2003).

The probability that two randomly selected persons do not speak the same language in a country. Source: Beck, Demirgüç-Kunt, and Levine (2003). The percentage of years that the country has been independent since 1776 . Source: Beck, Demirgüç-Kunt, and Levine (2003).

$(-1) * Z$ Z Score (Altman, 1968; 2000). Z-Score $=0.3 *($ Net Income/Total Assets $)+1.0 *$ (Sales/Total Assets $)+1.4 *$ (Retained Earnings/Total Assets) $+1.2 *$ (Working Capital/Total Assets)+0.6*(Market Value/Total Libliablity) Source: Compustat.

Share of banks that are majority-owned by foreigners. Source: Beck, Demirgüç-Kunt, and Levine (2006).

Indicator variable that equals one if the primary religion of the country is Protestantism, zero otherwise. Source: WVS survey.

Indicator variable that equals one for each of the Fama-French 48 industries, zero otherwise. Source:

http://mba.tuck.dartmouth.edu/pages/faculty/ken.french/Data_Library/det_4 8 ind_port.html.

Indicator variable that equals one for each year and zero otherwise.

Indicator variable that equals one for each loan purpose, including corporate purpose, debt repayment, takeover, working capital, and other purposes and zero otherwise. Source: DealScan.

Indicator variables that equals one for each loan type, including revolver/line, term loans and other loans and zero otherwise. Source: DealScan. 


\section{Table 1: Descriptive statistics}

This table presents the mean values of main country-level variables in Panel A and the descriptive statistics of main variables in regressions in Panel B.

Panel A: Descriptive statistics by country

\begin{tabular}{|c|c|c|c|c|c|c|c|c|c|c|c|c|}
\hline Country & $\begin{array}{l}\text { Lending } \\
\text { Corruption }\end{array}$ & $\begin{array}{l}\text { Economic } \\
\text { Growth }\end{array}$ & Inflation & $\begin{array}{c}L n \\
(G D P)\end{array}$ & $\begin{array}{c}\text { English } \\
\text { Law }\end{array}$ & $\begin{array}{l}\text { French } \\
\text { Law }\end{array}$ & $\begin{array}{l}\text { German } \\
\text { Law }\end{array}$ & $\begin{array}{c}\text { Rule } \\
\text { of } \\
\text { Law }\end{array}$ & $\begin{array}{c}\text { Political } \\
\text { Rights }\end{array}$ & $\begin{array}{l}\text { Credit } \\
\text { Rights }\end{array}$ & $\begin{array}{c}\text { Public Sector } \\
\text { Corruption }\end{array}$ & Obs \\
\hline Argentina & 1.52 & -0.07 & 0.07 & 8.84 & 0.00 & 1.00 & 0.00 & 5.35 & 5.72 & 1.00 & 0.43 & 49 \\
\hline Brazil & 1.28 & 0.12 & 0.12 & 8.42 & 0.00 & 1.00 & 0.00 & 6.32 & 5.74 & 1.00 & 0.17 & 106 \\
\hline Canada & 1.07 & 0.07 & 0.02 & 10.34 & 1.00 & 0.00 & 0.00 & 10.0 & 7.00 & 1.00 & -1.86 & 1,090 \\
\hline Chile & 1.20 & 0.07 & 0.05 & 8.73 & 0.00 & 1.00 & 0.00 & 7.02 & 6.37 & 2.00 & -1.45 & 42 \\
\hline Egypt & 2.31 & 0.16 & 0.09 & 7.55 & 0.00 & 1.00 & 0.00 & 4.17 & 2.00 & 4.00 & 0.52 & 2 \\
\hline France & 1.28 & 0.07 & 0.02 & 10.41 & 0.00 & 1.00 & 0.00 & 8.98 & 7.00 & 0.00 & -1.35 & 615 \\
\hline Germany & 1.51 & 0.06 & 0.01 & 10.42 & 0.00 & 0.00 & 1.00 & 9.23 & 7.00 & 3.00 & -1.86 & 347 \\
\hline India & 1.60 & 0.14 & 0.06 & 6.79 & 1.00 & 0.00 & 0.00 & 4.17 & 5.99 & 4.00 & 0.40 & 95 \\
\hline Indonesia & 2.51 & 0.12 & 0.12 & 7.46 & 0.00 & 1.00 & 0.00 & 3.98 & 5.06 & 4.00 & 0.86 & 16 \\
\hline Italy & 1.16 & 0.07 & 0.02 & 10.32 & 0.00 & 1.00 & 0.00 & 8.33 & 7.00 & 2.00 & -0.40 & 153 \\
\hline Malaysia & 1.70 & 0.08 & 0.04 & 8.49 & 1.00 & 0.00 & 0.00 & 6.78 & 3.55 & 4.00 & -0.27 & 454 \\
\hline Mexico & 2.04 & 0.09 & 0.12 & 8.76 & 0.00 & 1.00 & 0.00 & 5.35 & 5.47 & 0.00 & 0.28 & 180 \\
\hline Pakistan & 2.53 & 0.02 & 0.11 & 6.53 & 1.00 & 0.00 & 0.00 & 3.03 & 3.33 & 4.00 & 1.04 & 11 \\
\hline Peru & 2.20 & 0.04 & 0.05 & 7.78 & 0.00 & 1.00 & 0.00 & 2.50 & 4.32 & 0.00 & 0.36 & 17 \\
\hline Philippines & 2.18 & 0.02 & 0.07 & 7.02 & 0.00 & 1.00 & 0.00 & 2.73 & 5.74 & 0.00 & 0.59 & 189 \\
\hline Singapore & 1.26 & 0.09 & 0.01 & 10.24 & 1.00 & 0.00 & 0.00 & 8.57 & 3.01 & 4.00 & -2.19 & 289 \\
\hline South Africa & 1.11 & 0.00 & 0.08 & 8.26 & 1.00 & 0.00 & 0.00 & 4.42 & 6.62 & 3.00 & -0.58 & 44 \\
\hline Spain & 1.26 & 0.08 & 0.03 & 10.13 & 0.00 & 1.00 & 0.00 & 7.80 & 7.00 & 2.00 & -1.29 & 152 \\
\hline Sweden & 1.05 & 0.06 & 0.02 & 10.52 & 0.00 & 0.00 & 0.00 & 10.0 & 7.00 & 2.00 & -2.01 & 157 \\
\hline Thailand & 3.00 & 0.09 & 0.03 & 7.89 & 1.00 & 0.00 & 0.00 & 6.25 & 5.19 & 3.00 & 0.10 & 44 \\
\hline Turkey & 2.34 & 0.08 & 0.33 & 8.62 & 0.00 & 1.00 & 0.00 & 5.18 & 4.64 & 2.00 & 0.02 & 51 \\
\hline USA & 1.51 & 0.05 & 0.02 & 10.45 & 1.00 & 0.00 & 0.00 & 10.0 & 7.00 & 1.00 & -1.53 & 26,044 \\
\hline United Kingdom & 1.03 & 0.05 & 0.03 & 10.42 & 1.00 & 0.00 & 0.00 & 8.57 & 7.00 & 4.00 & -1.90 & 1,267 \\
\hline
\end{tabular}


Panel B: Bank loan-level variables

\begin{tabular}{lccccccc}
\hline Variables & Mean & Std. & P25 & Median & P75 & $\begin{array}{c}\text { No. of } \\
\text { countries }\end{array}$ & $\begin{array}{c}\text { No. of } \\
\text { obs. }\end{array}$ \\
\hline Spread & 181.000 & 116.000 & 75.000 & 175.000 & 250.000 & 23 & 22,116 \\
Ln (Spread) & 4.932 & 0.837 & 4.331 & 5.170 & 5.526 & 23 & 22,116 \\
Loan Size & 0.260 & 0.476 & 0.025 & 0.100 & 0.253 & 23 & 31,414 \\
Ln (Loan Size) & 0.188 & 0.261 & 0.025 & 0.095 & 0.225 & 23 & 31,414 \\
Loan Maturity & 48.440 & 31.570 & 24.000 & 48.000 & 60.000 & 23 & 31,414 \\
Ln (Loan Maturity) & 3.667 & 0.735 & 3.219 & 3.892 & 4.111 & 23 & 31,414 \\
Performance Pricing & 0.378 & 0.485 & 0.000 & 0.000 & 1.000 & 23 & 31,414 \\
Syndicated Loan & 0.712 & 0.453 & 0.000 & 1.000 & 1.000 & 23 & 31,414 \\
Number of Lenders & 9.925 & 9.858 & 3.000 & 7.000 & 13.000 & 23 & 22,376 \\
Lead Bank Allocation & 0.183 & 0.314 & 0.000 & 0.000 & 0.235 & 23 & 22,376 \\
\hline
\end{tabular}

Panel C: Firm-level variables

\begin{tabular}{lccccccc}
\hline Variables & Mean & Std. & P25 & Median & P75 & $\begin{array}{c}\text { No. of } \\
\text { countries }\end{array}$ & $\begin{array}{c}\text { No. of } \\
\text { obs. }\end{array}$ \\
\hline Ln (Firm Size) & 6.419 & 2.149 & 4.950 & 6.354 & 7.800 & 23 & 31,414 \\
Tangibility & 0.559 & 0.376 & 0.260 & 0.495 & 0.805 & 23 & 31,414 \\
Leverage & 0.542 & 0.261 & 0.375 & 0.514 & 0.673 & 23 & 31,414 \\
ROA & 0.022 & 0.167 & -0.006 & 0.047 & 0.098 & 23 & 31,414 \\
\hline
\end{tabular}

Panel D: Country-level variables

\begin{tabular}{lccccccc}
\hline Variables & Mean & Std. & P25 & Median & P75 & $\begin{array}{c}\text { No. of } \\
\text { countries }\end{array}$ & $\begin{array}{c}\text { No. of } \\
\text { obs. }\end{array}$ \\
\hline Lending Corruption & 1.680 & 0.581 & 1.204 & 1.511 & 2.198 & 23 & 23 \\
Economic Growth & 0.056 & 0.124 & -0.007 & 0.056 & 0.128 & 23 & 215 \\
Inflation & 0.077 & 0.161 & 0.016 & 0.034 & 0.075 & 23 & 344 \\
Ln (GDP) & 8.950 & 1.294 & 8.036 & 8.892 & 10.180 & 23 & 344 \\
English Law & 0.391 & 0.499 & 0.000 & 0.000 & 1.000 & 23 & 23 \\
French Law & 0.522 & 0.511 & 0.000 & 1.000 & 1.000 & 23 & 23 \\
German Law & 0.044 & 0.208 & 0.000 & 0.000 & 0.000 & 23 & 23 \\
Rule of Law & 6.467 & 2.455 & 4.167 & 6.317 & 8.567 & 23 & 23 \\
Political Rights & 5.696 & 1.460 & 5.000 & 6.000 & 7.000 & 23 & 23 \\
Creditor Rights & 2.217 & 1.506 & 1.000 & 2.000 & 4.000 & 23 & 23 \\
Public Sector Corruption & -0.518 & 1.060 & -1.530 & -0.270 & 0.400 & 23 & 23 \\
\hline
\end{tabular}




\section{Table 2: Relation between lending corruption and bank loan contracting}

The dependent variables are Ln (Loan Spread), Ln (Loan Size), and Ln (Maturity). The variable definitions are in Appendix A. For brevity, the coefficients for the industry, year, loan purpose, and loan type fixed effects are not reported. The regression coefficients are reported for each variable, followed by the heteroscedasticityrobust t-statistic in parentheses. ${ }^{*}, *$, and $* * *$ indicate statistical significance at the $10 \%, 5 \%$, and $1 \%$ levels, respectively.

\begin{tabular}{|c|c|c|c|}
\hline & $\begin{array}{c}(1) \\
\text { Ln (Loan Spread) }\end{array}$ & $\begin{array}{c}(2) \\
\text { Ln (Loan Size) }\end{array}$ & $\begin{array}{c}\text { (3) } \\
\text { Ln (Loan Maturity) }\end{array}$ \\
\hline Lending Corruption & $\begin{array}{c}-0.490 * * * \\
(-5.89)\end{array}$ & $\begin{array}{c}0.099 * * * \\
(3.59)\end{array}$ & $\begin{array}{c}0.138 * * * \\
(2.72)\end{array}$ \\
\hline Ln (Loan Size) & $\begin{array}{c}-0.632 * * * \\
(-26.19)\end{array}$ & & $\begin{array}{c}-0.149 * * * \\
(-6.82)\end{array}$ \\
\hline Ln (Loan Maturity) & $\begin{array}{c}0.117 * * * \\
(16.16)\end{array}$ & $\begin{array}{c}-0.013 * * * \\
(-6.74)\end{array}$ & \\
\hline Performance Pricing & $\begin{array}{c}-0.016^{*} \\
(-1.90)\end{array}$ & $\begin{array}{c}0.017 * * * \\
(6.70)\end{array}$ & $\begin{array}{c}0.284 * * * \\
(35.96)\end{array}$ \\
\hline Ln (Firm Size) & $\begin{array}{c}-0.151 * * * \\
(-43.23)\end{array}$ & $\begin{array}{c}0.077 * * * \\
(87.83)\end{array}$ & $\begin{array}{c}0.014 * * * \\
(4.89)\end{array}$ \\
\hline Tangibility & $\begin{array}{c}-0.186 * * * \\
(-13.80)\end{array}$ & $\begin{array}{l}0.007^{*} \\
(1.83)\end{array}$ & $\begin{array}{l}-0.009 \\
(-0.70)\end{array}$ \\
\hline Leverage & $\begin{array}{c}0.444 * * * \\
(27.03)\end{array}$ & $\begin{array}{c}-0.019 * * * \\
(-4.86)\end{array}$ & $\begin{array}{c}0.215^{* * *} \\
(14.82)\end{array}$ \\
\hline$R O A$ & $\begin{array}{c}-1.078 * * * \\
(-24.57)\end{array}$ & $\begin{array}{c}-0.030 * * * \\
(-5.11)\end{array}$ & $\begin{array}{c}0.402 * * * \\
(16.25)\end{array}$ \\
\hline Economic Growth & $\begin{array}{l}-0.157 \\
(-1.08)\end{array}$ & $\begin{array}{c}-0.097 * * \\
(-2.17)\end{array}$ & $\begin{array}{l}-0.151 \\
(-1.22)\end{array}$ \\
\hline Inflation & $\begin{array}{l}1.229 * * * \\
(5.23)\end{array}$ & $\begin{array}{c}-0.370 * * * \\
(-7.02)\end{array}$ & $\begin{array}{c}-1.032 * * * \\
(-5.31)\end{array}$ \\
\hline $\operatorname{Ln}(G D P)$ & $\begin{array}{c}0.0430 \\
(0.84)\end{array}$ & $\begin{array}{l}0.003 \\
(0.21)\end{array}$ & $\begin{array}{c}-0.077 * * \\
(-2.42)\end{array}$ \\
\hline English Law & $\begin{array}{c}0.393 * * * \\
(6.06)\end{array}$ & $\begin{array}{c}-0.064 * * * \\
(-2.60)\end{array}$ & $\begin{array}{c}-0.330 * * * \\
(-6.38)\end{array}$ \\
\hline French Law & $\begin{array}{l}-0.154 \\
(-1.60)\end{array}$ & $\begin{array}{l}0.004 \\
(0.11)\end{array}$ & $\begin{array}{c}-0.136 * * \\
(-2.04)\end{array}$ \\
\hline German Law & $\begin{array}{c}0.626 * * * \\
(6.22)\end{array}$ & $\begin{array}{l}-0.016 \\
(-0.47)\end{array}$ & $\begin{array}{c}-0.363 * * * \\
(-5.23)\end{array}$ \\
\hline Rule of Law & $\begin{array}{c}0.0160 \\
(0.49)\end{array}$ & $\begin{array}{c}0.019 * * \\
(2.20)\end{array}$ & $\begin{array}{l}-0.013 \\
(-0.72)\end{array}$ \\
\hline Political Rights & $\begin{array}{c}-0.102 * * * \\
(-3.78)\end{array}$ & $\begin{array}{c}0.036^{* * *} \\
(7.86)\end{array}$ & $\begin{array}{c}0.054 * * * \\
(5.14)\end{array}$ \\
\hline Creditor Rights & $\begin{array}{c}-0.172 * * * \\
(-7.97)\end{array}$ & $\begin{array}{c}0.034 * * * \\
(5.56)\end{array}$ & $\begin{array}{c}0.044 * * * \\
(3.69)\end{array}$ \\
\hline Public Sector Corruption & $\begin{array}{c}0.369 * * * \\
(5.32)\end{array}$ & $\begin{array}{l}-0.007 \\
(-0.42)\end{array}$ & $\begin{array}{c}-0.188 * * * \\
(-4.99)\end{array}$ \\
\hline Intercept & $\begin{array}{c}6.525 * * * \\
(21.81)\end{array}$ & $\begin{array}{c}-0.913 * * * \\
(-11.66)\end{array}$ & $\begin{array}{c}4.141^{* * *} \\
(21.40)\end{array}$ \\
\hline Loan Purpose/Loan Type & Included & Included & Included \\
\hline Industry/Year & Included & Included & Included \\
\hline Number of observations & 22,116 & 31,414 & 31,414 \\
\hline Adjusted $R^{2}$ & 0.534 & 0.450 & 0.213 \\
\hline
\end{tabular}


Table 3: Relation between lending corruption and bank loan contracting: Anti-corruption law reforms

The dependent variables are Ln (Loan Spread), Ln (Loan Size), and Ln (Maturity). The variable definitions are in Appendix A. For brevity, the coefficients for the industry, year, loan purpose, and loan type fixed effects are not reported. The regression coefficients are reported for each variable, followed by the heteroscedasticity-robust tstatistic in parentheses. ${ }^{*}, *$, and $* * *$ indicate statistical significance at the $10 \%, 5 \%$, and $1 \%$ levels, respectively.

\begin{tabular}{|c|c|c|c|}
\hline & $\begin{array}{c}(1) \\
\text { Ln (Loan Spread) }\end{array}$ & $\begin{array}{c}(2) \\
\text { Ln (Loan Size) }\end{array}$ & $\begin{array}{c}(3) \\
\text { Ln (Loan Maturity) }\end{array}$ \\
\hline Anti-Corruption Law & $\begin{array}{c}0.219 * * \\
(1.97)\end{array}$ & $\begin{array}{l}0.035 \\
(1.11)\end{array}$ & $\begin{array}{c}-0.238^{* *} \\
(-2.14)\end{array}$ \\
\hline Ln (Loan Size) & $\begin{array}{c}-0.410 * * * \\
(-20.87)\end{array}$ & & $\begin{array}{c}0.108 * * * \\
(4.81)\end{array}$ \\
\hline Ln (Loan Maturity) & $\begin{array}{c}0.050 * * * \\
(8.72)\end{array}$ & $\begin{array}{c}0.009 * * * \\
(4.81)\end{array}$ & \\
\hline Performance Pricing & $\begin{array}{c}-0.052 * * * \\
(-6.70)\end{array}$ & $\begin{array}{c}0.035 * * * \\
(12.91)\end{array}$ & $\begin{array}{c}0.194 * * * \\
(20.18)\end{array}$ \\
\hline Ln (Firm Size) & $\begin{array}{c}-0.101 * * * \\
(-13.38)\end{array}$ & $\begin{array}{c}0.053 * * * \\
(22.53)\end{array}$ & $\begin{array}{l}0.015^{*} \\
(1.79)\end{array}$ \\
\hline Tangibility & $\begin{array}{c}-0.092 * * * \\
(-3.51)\end{array}$ & $\begin{array}{l}-0.009 \\
(-0.98)\end{array}$ & $\begin{array}{l}-0.011 \\
(-0.37)\end{array}$ \\
\hline Leverage & $\begin{array}{c}0.171 * * * \\
(7.52)\end{array}$ & $\begin{array}{l}-0.006 \\
(-0.75)\end{array}$ & $\begin{array}{c}-0.090 * * * \\
(-3.36)\end{array}$ \\
\hline$R O A$ & $\begin{array}{c}-0.695 * * * \\
(-18.26)\end{array}$ & $\begin{array}{c}0.023 * * \\
(2.05)\end{array}$ & $\begin{array}{c}0.254 * * * \\
(6.35)\end{array}$ \\
\hline Economic Growth & $\begin{array}{l}-0.225 \\
(-1.62)\end{array}$ & $\begin{array}{c}-0.068 * * \\
(-2.06)\end{array}$ & $\begin{array}{l}-0.060 \\
(-0.51)\end{array}$ \\
\hline Inflation & $\begin{array}{c}1.369 * * * \\
(7.36)\end{array}$ & $\begin{array}{c}-0.199 * * * \\
(-3.17)\end{array}$ & $\begin{array}{c}-1.030 * * * \\
(-4.63)\end{array}$ \\
\hline $\operatorname{Ln}(G D P)$ & $\begin{array}{l}0.009 \\
(0.25)\end{array}$ & $\begin{array}{l}0.009 \\
(1.16)\end{array}$ & $\begin{array}{l}-0.007 \\
(-0.26)\end{array}$ \\
\hline Intercept & $\begin{array}{c}5.148 * * * \\
(13.19)\end{array}$ & $\begin{array}{c}-0.333 * * * \\
(-4.06)\end{array}$ & $\begin{array}{c}3.965 * * * \\
(13.71)\end{array}$ \\
\hline Loan Purpose/Loan Type & Included & Included & Included \\
\hline Year & Included & Included & Included \\
\hline Firm fixed effects & Included & Included & Included \\
\hline Number of observations & 22,116 & 31,414 & 31,414 \\
\hline Overall $R^{2}$ & 0.435 & 0.412 & 0.157 \\
\hline
\end{tabular}


Table 4: Relation between lending corruption and bank loan contracting: IV Estimation

The dependent variables are Ln (Loan Spread), Ln (Loan Size), and Ln (Maturity). The variable definitions are in Appendix A. For brevity, the coefficients for the industry, year, loan purpose, and loan type fixed effects are not reported. The regression coefficients are reported for each variable, followed by the heteroscedasticity-robust tstatistic in parentheses. ${ }^{*}, *$, and $* * *$ indicate statistical significance at the $10 \%, 5 \%$, and $1 \%$ levels, respectively.

\begin{tabular}{|c|c|c|c|}
\hline & $\begin{array}{c}\text { (1) } \\
\text { Ln (Loan Spread) }\end{array}$ & $\begin{array}{c}(2) \\
\text { Ln (Loan Size) }\end{array}$ & $\begin{array}{c}\text { (3) } \\
\text { Ln (Loan Maturity) }\end{array}$ \\
\hline Lending Corruption & $\begin{array}{c}-0.213^{*} \\
(-1.84)\end{array}$ & $\begin{array}{c}0.095^{* * *} \\
(3.45)\end{array}$ & $\begin{array}{c}0.208 * * * \\
(3.25)\end{array}$ \\
\hline Ln (Loan Size) & $\begin{array}{c}-0.630 * * * \\
(-26.08)\end{array}$ & & $\begin{array}{c}-0.150 * * * \\
(-6.89)\end{array}$ \\
\hline Ln (Loan Maturity) & $\begin{array}{c}0.117 * * * \\
(16.14)\end{array}$ & $\begin{array}{c}-0.013 * * * \\
(-6.74)\end{array}$ & \\
\hline Performance Pricing & $\begin{array}{c}-0.017 * * \\
(-2.05)\end{array}$ & $\begin{array}{c}0.017 * * * \\
(6.74)\end{array}$ & $\begin{array}{c}0.283 * * * \\
(35.92)\end{array}$ \\
\hline Ln (Firm Size) & $\begin{array}{c}-0.151^{* * * *} \\
(-43.34)\end{array}$ & $\begin{array}{c}0.077^{* * * *} \\
(87.90)\end{array}$ & $\begin{array}{c}0.014 * * * \\
(4.89)\end{array}$ \\
\hline Tangibility & $\begin{array}{c}-0.184 * * * \\
(-13.71)\end{array}$ & $\begin{array}{c}0.007^{*} \\
(1.83)\end{array}$ & $\begin{array}{l}-0.008 \\
(-0.66)\end{array}$ \\
\hline Leverage & $\begin{array}{c}0.443 * * * \\
(27.01)\end{array}$ & $\begin{array}{c}-0.019 * * * \\
(-4.86)\end{array}$ & $\begin{array}{c}0.214 * * * \\
(14.81)\end{array}$ \\
\hline$R O A$ & $\begin{array}{c}-1.078 * * * \\
(-24.58)\end{array}$ & $\begin{array}{c}-0.030 * * * \\
(-5.13)\end{array}$ & $\begin{array}{c}0.403 * * * \\
(16.31)\end{array}$ \\
\hline Economic Growth & $\begin{array}{l}-0.137 \\
(-0.94)\end{array}$ & $\begin{array}{c}-0.097 * * \\
(-2.17)\end{array}$ & $\begin{array}{l}-0.149 \\
(-1.20)\end{array}$ \\
\hline Inflation & $\begin{array}{c}1.121^{* * *} \\
(4.63)\end{array}$ & $\begin{array}{c}-0.369 * * * \\
(-7.05)\end{array}$ & $\begin{array}{c}-1.045^{* * *} \\
(-5.39)\end{array}$ \\
\hline $\operatorname{Ln}(G D P)$ & $\begin{array}{l}-0.049 \\
(-0.83)\end{array}$ & $\begin{array}{l}0.004 \\
(0.28)\end{array}$ & $\begin{array}{c}-0.094 * * * \\
(-2.80)\end{array}$ \\
\hline English Law & $\begin{array}{c}0.372 * * * \\
(5.76)\end{array}$ & $\begin{array}{c}-0.063^{* * *} \\
(-2.60)\end{array}$ & $\begin{array}{c}-0.335^{* * *} \\
(-6.48)\end{array}$ \\
\hline French Law & $\begin{array}{l}-0.063 \\
(-0.63)\end{array}$ & $\begin{array}{l}0.002 \\
(0.06)\end{array}$ & $\begin{array}{l}-0.105 \\
(-1.52)\end{array}$ \\
\hline German Law & $\begin{array}{c}0.489 * * * \\
(4.55)\end{array}$ & $\begin{array}{l}-0.014 \\
(-0.41)\end{array}$ & $\begin{array}{c}-0.397 * * * \\
(-5.54)\end{array}$ \\
\hline Rule of Law & $\begin{array}{l}0.039 \\
(1.18)\end{array}$ & $\begin{array}{c}0.019^{* *} \\
(2.23)\end{array}$ & $\begin{array}{l}-0.005 \\
(-0.27)\end{array}$ \\
\hline Political Rights & $\begin{array}{c}-0.067 * * \\
(-2.40)\end{array}$ & $\begin{array}{c}0.036 * * * \\
(8.07)\end{array}$ & $\begin{array}{c}0.060 * * * \\
(5.49)\end{array}$ \\
\hline Creditor Rights & $\begin{array}{c}-0.140 * * * \\
(-6.06)\end{array}$ & $\begin{array}{c}0.034 * * * \\
(5.92)\end{array}$ & $\begin{array}{c}0.053^{* * *} \\
(4.14)\end{array}$ \\
\hline Public Sector Corruption & $\begin{array}{c}0.247 * * * \\
(3.02)\end{array}$ & $\begin{array}{c}-0.00500 \\
(-0.28)\end{array}$ & $\begin{array}{c}-0.219 * * * \\
(-5.19)\end{array}$ \\
\hline Intercept & $\begin{array}{c}6.393 * * * \\
(21.30)\end{array}$ & $\begin{array}{c}-0.907 * * * \\
(-11.94)\end{array}$ & $\begin{array}{c}4.045^{* * *} \\
(20.55)\end{array}$ \\
\hline Loan Purpose/Loan Type & Included & Included & Included \\
\hline Industry/Year & Included & Included & Included \\
\hline Number of observations & 22,116 & 31,414 & 31,414 \\
\hline Adjusted $R^{2}$ & 0.534 & 0.450 & 0.213 \\
\hline
\end{tabular}


Table 5: Cross-sectional test: Relation between lending corruption and bank loan contracting

The dependent variables are Ln (Loan Spread), Ln (Loan Size), and Ln (Maturity). The variable definitions are in Appendix A. For brevity, the coefficients for the industry, year, loan purpose, and loan type fixed effects are not reported. The regression coefficients are reported for each variable, followed by the heteroscedasticity-robust tstatistic in parentheses. ${ }^{* * *}$, and $* * *$ indicate statistical significance at the $10 \%, 5 \%$, and $1 \%$ levels, respectively. Panel A: Financial distress

\begin{tabular}{|c|c|c|c|}
\hline & $\begin{array}{c}(1) \\
\text { Ln (Loan Spread) }\end{array}$ & $\begin{array}{c}(2) \\
\text { Ln (Loan Size) }\end{array}$ & $\begin{array}{c}\text { (3) } \\
\text { Ln (Loan Maturity) }\end{array}$ \\
\hline Lending Corruption* Financial Distress & $\begin{array}{l}-0.019 \\
(-1.02)\end{array}$ & $\begin{array}{l}0.025 * * * \\
(5.81)\end{array}$ & $\begin{array}{c}0.023^{* *} \\
(1.97)\end{array}$ \\
\hline Lending Corruption & $\begin{array}{c}-0.507 * * * \\
(-5.66)\end{array}$ & $\begin{array}{c}0.146^{* * *} \\
(4.98)\end{array}$ & $\begin{array}{l}0.182 * * * \\
\quad(3.28)\end{array}$ \\
\hline Financial Distress & $\begin{array}{l}0.053^{*} \\
(1.94)\end{array}$ & $\begin{array}{c}-0.036^{* * *} \\
(-5.43)\end{array}$ & $\begin{array}{l}-0.027 \\
(-1.58)\end{array}$ \\
\hline Ln (Loan Size) & $\begin{array}{c}-0.635^{* * * *} \\
(-26.31)\end{array}$ & & $\begin{array}{c}-0.152 * * * \\
(-6.98)\end{array}$ \\
\hline Ln (Loan Maturity) & $\begin{array}{c}0.114 * * * \\
(15.90)\end{array}$ & $\begin{array}{c}-0.013 * * * \\
(-6.89)\end{array}$ & \\
\hline Performance Pricing & $\begin{array}{c}-0.019 * * \\
(-2.26)\end{array}$ & $\begin{array}{c}0.017 * * * \\
(6.82)\end{array}$ & $\begin{array}{c}0.284 * * * \\
(35.96)\end{array}$ \\
\hline Ln (Firm Size) & $\begin{array}{c}-0.158 * * * \\
(-45.00)\end{array}$ & $\begin{array}{c}0.076^{* * *} \\
(88.04)\end{array}$ & $\begin{array}{c}0.012 * * * \\
(4.43)\end{array}$ \\
\hline Tangibility & $\begin{array}{c}-0.198 * * * \\
(-14.83)\end{array}$ & $\begin{array}{l}0.006 \\
(1.58)\end{array}$ & $\begin{array}{l}-0.012 \\
(-0.99)\end{array}$ \\
\hline Leverage & $\begin{array}{c}0.339 * * * \\
(18.84)\end{array}$ & $\begin{array}{c}-0.029 * * * \\
(-6.36)\end{array}$ & $\begin{array}{c}0.186^{* * *} \\
(11.59)\end{array}$ \\
\hline$R O A$ & $\begin{array}{c}-0.937 * * * \\
(-21.11)\end{array}$ & $\begin{array}{c}-0.021 * * * \\
(-3.42)\end{array}$ & $\begin{array}{c}0.430 * * * \\
(16.54)\end{array}$ \\
\hline Economic Growth & $\begin{array}{l}-0.130 \\
(-0.90)\end{array}$ & $\begin{array}{l}-0.083^{*} \\
(-1.86)\end{array}$ & $\begin{array}{l}-0.133 \\
(-1.07)\end{array}$ \\
\hline Inflation & $\begin{array}{c}1.342 * * * \\
(5.03)\end{array}$ & $\begin{array}{c}-0.402 * * * \\
(-7.59)\end{array}$ & $\begin{array}{c}-1.050 * * * \\
(-5.41)\end{array}$ \\
\hline $\operatorname{Ln}(G D P)$ & $\begin{array}{l}0.047 \\
(0.92)\end{array}$ & $\begin{array}{l}0.004 \\
(0.29)\end{array}$ & $\begin{array}{c}-0.074 * * \\
(-2.32)\end{array}$ \\
\hline English Law & $\begin{array}{l}0.383 * * * \\
(5.92)\end{array}$ & $\begin{array}{c}-0.062 * * \\
(-2.51)\end{array}$ & $\begin{array}{c}-0.329 * * * \\
(-6.37)\end{array}$ \\
\hline French Law & $\begin{array}{l}-0.154 \\
(-1.60)\end{array}$ & $\begin{array}{l}0.005 \\
(0.16)\end{array}$ & $\begin{array}{c}-0.136^{* *} \\
(-2.04)\end{array}$ \\
\hline German Law & $\begin{array}{c}0.607 * * * \\
(6.01)\end{array}$ & $\begin{array}{l}-0.009 \\
(-0.27)\end{array}$ & $\begin{array}{c}-0.359 * * * \\
(-5.16)\end{array}$ \\
\hline Rule of Law & $\begin{array}{l}0.021 \\
(0.65)\end{array}$ & $\begin{array}{c}0.020^{* *} \\
(2.29)\end{array}$ & $\begin{array}{l}-0.013 \\
(-0.70)\end{array}$ \\
\hline Political Rights & $\begin{array}{c}-0.095^{* * *} \\
(-3.58)\end{array}$ & $\begin{array}{l}0.035^{* * *} \\
(7.79)\end{array}$ & $\begin{array}{l}0.054 * * * \\
(5.16)\end{array}$ \\
\hline Creditor Rights & $\begin{array}{c}-0.164 * * * \\
(-7.51)\end{array}$ & $\begin{array}{c}0.033 * * * \\
(5.38)\end{array}$ & $\begin{array}{c}0.043 * * * \\
(3.61)\end{array}$ \\
\hline Public Sector Corruption & $\begin{array}{c}0.383 * * * \\
(5.45)\end{array}$ & $\begin{array}{l}-0.003 \\
(-0.18)\end{array}$ & $\begin{array}{c}-0.184 * * * \\
(-4.87)\end{array}$ \\
\hline Intercept & $\begin{array}{c}6.592 * * * \\
(21.95)\end{array}$ & $\begin{array}{c}-0.980 * * * \\
(-12.32)\end{array}$ & $\begin{array}{c}4.082 * * * \\
(20.76)\end{array}$ \\
\hline Loan Purpose/Loan Type & Included & Included & Included \\
\hline Industry/Year & Included & Included & Included \\
\hline Number of observations & 22,116 & 31,414 & 31,414 \\
\hline Adjusted $R^{2}$ & 0.538 & 0.451 & 0.214 \\
\hline
\end{tabular}


Panel B: Foreign ownership

\begin{tabular}{|c|c|c|c|}
\hline & $\begin{array}{c}(1) \\
\text { Ln (Loan Spread) }\end{array}$ & $\begin{array}{c}(2) \\
\text { Ln (Loan Size) }\end{array}$ & $\begin{array}{c}\text { (3) } \\
\text { Ln (Loan Maturity) }\end{array}$ \\
\hline Lending Corruption* Foreign Ownership & $\begin{array}{l}0.021^{*} \\
(1.77)\end{array}$ & $\begin{array}{c}-0.008 * * * \\
(-2.87)\end{array}$ & $\begin{array}{l}0.001 \\
(0.06)\end{array}$ \\
\hline Lending Corruption & $\begin{array}{c}-1.018^{* * *} \\
(-4.59)\end{array}$ & $\begin{array}{c}0.154 * * * \\
(3.02)\end{array}$ & $\begin{array}{l}-0.084 \\
(-1.00)\end{array}$ \\
\hline Foreign Ownership & $\begin{array}{c}-0.060 * * * \\
(-2.91)\end{array}$ & $\begin{array}{c}0.017 * * * \\
(3.54)\end{array}$ & $\begin{array}{l}-0.007 \\
(-0.49)\end{array}$ \\
\hline Ln (Loan Size) & $\begin{array}{c}-0.649 * * * \\
(-25.10)\end{array}$ & & $\begin{array}{c}-0.149 * * * \\
(-6.22)\end{array}$ \\
\hline Ln (Loan Maturity) & $\begin{array}{c}0.122 * * * \\
(16.06)\end{array}$ & $\begin{array}{c}-0.012 * * * \\
(-6.14)\end{array}$ & \\
\hline Performance Pricing & $\begin{array}{c}-0.037 * * * \\
(-4.40)\end{array}$ & $\begin{array}{l}0.014 * * * \\
(5.72)\end{array}$ & $\begin{array}{c}0.299 * * * \\
(36.49)\end{array}$ \\
\hline Ln (Firm Size) & $\begin{array}{c}-0.153 * * * \\
(-41.67)\end{array}$ & $\begin{array}{c}0.076^{* * *} \\
(82.89)\end{array}$ & $\begin{array}{c}0.016 * * * \\
(5.27)\end{array}$ \\
\hline Tangibility & $\begin{array}{c}-0.206^{* * *} \\
(-14.84)\end{array}$ & $\begin{array}{c}0.009 * * \\
(2.48)\end{array}$ & $\begin{array}{c}-0.00400 \\
(-0.33)\end{array}$ \\
\hline Leverage & $\begin{array}{c}0.461 * * * \\
(27.26)\end{array}$ & $\begin{array}{c}-0.017 * * * \\
(-4.32)\end{array}$ & $\begin{array}{c}0.199 * * * \\
(13.26)\end{array}$ \\
\hline$R O A$ & $\begin{array}{c}-1.057 * * * \\
(-23.58)\end{array}$ & $\begin{array}{c}-0.027 * * * \\
(-4.75)\end{array}$ & $\begin{array}{c}0.393 * * * \\
(15.55)\end{array}$ \\
\hline Economic Growth & $\begin{array}{l}-0.346 \\
(-1.21)\end{array}$ & $\begin{array}{c}-0.304 * * * \\
(-3.72)\end{array}$ & $\begin{array}{l}-0.218 \\
(-1.21)\end{array}$ \\
\hline Inflation & $\begin{array}{l}0.451 \\
(0.98)\end{array}$ & $\begin{array}{c}-0.407 * * * \\
(-4.81)\end{array}$ & $\begin{array}{c}-1.033 * * * \\
(-3.93)\end{array}$ \\
\hline $\operatorname{Ln}(G D P)$ & $\begin{array}{c}-0.264 * * * \\
(-3.20)\end{array}$ & $\begin{array}{c}0.051 * * \\
(2.01)\end{array}$ & $\begin{array}{c}-0.0960 \\
(-1.47)\end{array}$ \\
\hline English Law & $\begin{array}{c}0.911 * * * \\
(6.28)\end{array}$ & $\begin{array}{c}-0.231 * * * \\
(-5.63)\end{array}$ & $\begin{array}{c}-0.297 * * * \\
(-2.87)\end{array}$ \\
\hline French Law & $\begin{array}{c}1.156^{* * *} \\
(3.69)\end{array}$ & $\begin{array}{c}-0.309 * * * \\
(-4.09)\end{array}$ & $\begin{array}{l}-0.183 \\
(-0.93)\end{array}$ \\
\hline German Law & $\begin{array}{c}1.184 * * * \\
(6.78)\end{array}$ & $\begin{array}{l}-0.036 \\
(-0.78)\end{array}$ & $\begin{array}{c}-0.195 * * \\
(-2.21)\end{array}$ \\
\hline Rule of Law & $\begin{array}{l}0.017 \\
(0.33)\end{array}$ & $\begin{array}{c}0.037 * * \\
(2.48)\end{array}$ & $\begin{array}{l}-0.013 \\
(-0.32)\end{array}$ \\
\hline Political Rights & $\begin{array}{c}-0.349 * * * \\
(-3.91)\end{array}$ & $\begin{array}{c}0.052 * * * \\
(3.61)\end{array}$ & $\begin{array}{l}-0.038 \\
(-1.23)\end{array}$ \\
\hline Creditor Rights & $\begin{array}{c}-0.365^{* * * *} \\
(-5.32)\end{array}$ & $\begin{array}{c}0.0120 \\
(0.78)\end{array}$ & $\begin{array}{l}-0.025 \\
(-0.77)\end{array}$ \\
\hline Public Sector Corruption & $\begin{array}{c}-0.373 * * \\
(-2.27)\end{array}$ & $\begin{array}{l}0.203 * * * \\
(4.73)\end{array}$ & $\begin{array}{l}-0.149 \\
(-1.24)\end{array}$ \\
\hline Intercept & $\begin{array}{l}10.917 * * * \\
(10.05)\end{array}$ & $\begin{array}{c}-1.284 * * * \\
(-5.18)\end{array}$ & $\begin{array}{c}5.402 * * * \\
(11.17)\end{array}$ \\
\hline Loan Purpose/Loan Type & Included & Included & Included \\
\hline Industry/Year & Included & Included & Included \\
\hline Number of observations & 20,393 & 28,124 & 28,124 \\
\hline Adjusted $R^{2}$ & 0.535 & 0.460 & 0.224 \\
\hline
\end{tabular}


Panel C: Religion

\begin{tabular}{|c|c|c|c|}
\hline & $\begin{array}{c}(1) \\
\text { Ln (Loan Spread) }\end{array}$ & $\begin{array}{c}(2) \\
\text { Ln (Loan Size) }\end{array}$ & $\begin{array}{c}(3) \\
\text { Ln (Loan Maturity) }\end{array}$ \\
\hline Lending Corruption* Protestant & $\begin{array}{c}1.453 * * * \\
(4.04)\end{array}$ & $\begin{array}{c}-0.180 * * \\
(-2.30)\end{array}$ & $\begin{array}{c}-1.015 * * * \\
(-5.38)\end{array}$ \\
\hline Lending Corruption & $\begin{array}{c}-1.696^{* * *} \\
(-8.30)\end{array}$ & $\begin{array}{l}0.191 * * * \\
(3.70)\end{array}$ & $\begin{array}{c}0.641 * * * \\
(4.54)\end{array}$ \\
\hline Protestant & $\begin{array}{c}-1.665^{* * *} \\
(-3.33)\end{array}$ & $\begin{array}{l}0.184^{*} \\
(1.69)\end{array}$ & $\begin{array}{c}1.366^{* * *} \\
(5.25)\end{array}$ \\
\hline Ln (Loan Size) & $\begin{array}{c}-0.633 * * * \\
(-26.25)\end{array}$ & & $\begin{array}{c}-0.149^{* * *} \\
(-6.84)\end{array}$ \\
\hline Ln (Loan Maturity) & $\begin{array}{c}0.117 * * * \\
(16.22)\end{array}$ & $\begin{array}{c}-0.013 * * * \\
(-6.76)\end{array}$ & \\
\hline Performance Pricing & $\begin{array}{c}-0.018 * * \\
(-2.13)\end{array}$ & $\begin{array}{c}0.018 * * * \\
(7.23)\end{array}$ & $\begin{array}{c}0.285 * * * \\
(35.88)\end{array}$ \\
\hline Ln (Firm Size) & $\begin{array}{c}-0.150 * * * \\
(-43.04)\end{array}$ & $\begin{array}{c}0.077 * * * \\
(87.45)\end{array}$ & $\begin{array}{c}0.014 * * * \\
(4.99)\end{array}$ \\
\hline Tangibility & $\begin{array}{c}-0.186^{* * *} \\
(-13.87)\end{array}$ & $\begin{array}{l}0.006 \\
(1.62)\end{array}$ & $\begin{array}{l}-0.007 \\
(-0.60)\end{array}$ \\
\hline Leverage & $\begin{array}{c}0.443 * * * \\
(27.03)\end{array}$ & $\begin{array}{c}-0.019 * * * \\
(-4.67)\end{array}$ & $\begin{array}{c}0.214 * * * \\
(14.75)\end{array}$ \\
\hline$R O A$ & $\begin{array}{c}-1.081 * * * \\
(-24.63)\end{array}$ & $\begin{array}{c}-0.031 * * * \\
(-5.27)\end{array}$ & $\begin{array}{c}0.400 * * * \\
(16.16)\end{array}$ \\
\hline Economic Growth & $\begin{array}{l}-0.083 \\
(-0.52)\end{array}$ & $\begin{array}{c}-0.127 * * * \\
(-2.69)\end{array}$ & $\begin{array}{l}-0.100 \\
(-0.77)\end{array}$ \\
\hline Inflation & $\begin{array}{l}1.038 * * * \\
(4.60)\end{array}$ & $\begin{array}{c}-0.327 * * * \\
(-6.28)\end{array}$ & $\begin{array}{c}-1.049 * * * \\
(-5.19)\end{array}$ \\
\hline $\operatorname{Ln}(G D P)$ & $\begin{array}{l}0.078 \\
(1.14)\end{array}$ & $\begin{array}{c}0.042 * * \\
(2.39)\end{array}$ & $\begin{array}{c}-0.165^{* * *} \\
(-3.47)\end{array}$ \\
\hline English Law & $\begin{array}{c}0.271 * * \\
(2.41)\end{array}$ & $\begin{array}{c}-0.054^{*} \\
(-1.67)\end{array}$ & $\begin{array}{l}-0.117 \\
(-1.58)\end{array}$ \\
\hline French Law & $\begin{array}{l}-0.146 \\
(-1.06)\end{array}$ & $\begin{array}{l}-0.057 \\
(-1.47)\end{array}$ & $\begin{array}{l}0.103 \\
(1.04)\end{array}$ \\
\hline German Law & $\begin{array}{c}0.461^{* *} \\
(2.49)\end{array}$ & $\begin{array}{l}0.029 \\
(0.60)\end{array}$ & $\begin{array}{l}-0.041 \\
(-0.37)\end{array}$ \\
\hline Rule of Law & $\begin{array}{l}-0.048 \\
(-1.03)\end{array}$ & $\begin{array}{l}0.008 \\
(0.82)\end{array}$ & $\begin{array}{c}0.058^{* *} \\
(2.20)\end{array}$ \\
\hline Political Rights & $\begin{array}{c}-0.154 * * * \\
(-4.30)\end{array}$ & $\begin{array}{c}0.043 * * * \\
(5.34)\end{array}$ & $\begin{array}{l}0.040^{*} \\
(1.95)\end{array}$ \\
\hline Creditor Rights & $\begin{array}{c}-0.162 * * * \\
(-5.20)\end{array}$ & $\begin{array}{c}0.022 * * * \\
(2.84)\end{array}$ & $\begin{array}{l}-0.003 \\
(-0.19)\end{array}$ \\
\hline Public Sector Corruption & $\begin{array}{c}0.406^{* * *} \\
(5.18)\end{array}$ & $\begin{array}{l}0.017 \\
(0.91)\end{array}$ & $\begin{array}{c}-0.228 * * * \\
(-5.01)\end{array}$ \\
\hline Intercept & $\begin{array}{c}8.635 * * * \\
(16.51)\end{array}$ & $\begin{array}{c}-1.269 * * * \\
(-9.33)\end{array}$ & $\begin{array}{l}3.593 * * * \\
(8.89)\end{array}$ \\
\hline Loan Purpose/Loan Type & Included & Included & Included \\
\hline Industry/Year & Included & Included & Included \\
\hline Number of observations & 22,116 & 31,414 & 31,414 \\
\hline Adjusted $R^{2}$ & 0.535 & 0.450 & 0.214 \\
\hline
\end{tabular}




\section{Table 6: Relation between lending corruption and loan syndication}

The dependent variables are Syndicated Loan, Number of Lenders, and Lead Bank Allocation. The variable definitions are in Appendix A. For brevity, the coefficients for the industry, year, loan purpose, and loan type fixed effects are not reported. The regression coefficients are reported for each variable, followed by the heteroscedasticity-robust $\mathrm{t}$ - or $\mathrm{z}$-statistic in parentheses. ${ }^{*}, * *$, and $* * *$ indicate statistical significance at the $10 \%$, $5 \%$, and $1 \%$ levels, respectively.

\begin{tabular}{|c|c|c|c|}
\hline & $\begin{array}{c}\text { (1) } \\
\text { Syndicated Loan }\end{array}$ & $\begin{array}{c}\text { (2) } \\
\text { Number of Lenders }\end{array}$ & $\begin{array}{c}\text { (3) } \\
\text { Lead Bank Allocation }\end{array}$ \\
\hline Lending Corruption & $\begin{array}{c}-1.565^{* * *} \\
(-6.34)\end{array}$ & $\begin{array}{c}-0.176^{* * * *} \\
(-2.87)\end{array}$ & $\begin{array}{c}0.108^{* * *} \\
(3.79)\end{array}$ \\
\hline Ln (Loan Size) & $\begin{array}{l}2.641 * * * \\
(8.92)\end{array}$ & $\begin{array}{c}0.659^{* * * *} \\
(28.90)\end{array}$ & $\begin{array}{l}0.005 \\
(0.51)\end{array}$ \\
\hline Ln (Loan Maturity) & $\begin{array}{l}0.503^{* * * *} \\
(19.05)\end{array}$ & $\begin{array}{c}0.088^{* * *} \\
(10.03)\end{array}$ & $\begin{array}{l}0.011 * * * \\
(3.35)\end{array}$ \\
\hline Performance Pricing & $\begin{array}{c}0.978 * * * \\
(27.01)\end{array}$ & $\begin{array}{c}0.312 * * * \\
(24.16)\end{array}$ & $\begin{array}{l}0.001 \\
(0.24)\end{array}$ \\
\hline Ln (Firm Size) & $\begin{array}{c}0.536 * * * \\
(32.55)\end{array}$ & $\begin{array}{c}0.161 * * * \\
(37.14)\end{array}$ & $\begin{array}{c}-0.020 * * * \\
(-11.89)\end{array}$ \\
\hline Tangibility & $\begin{array}{l}0.045 \\
(0.85)\end{array}$ & $\begin{array}{c}-0.050^{* * *} \\
(-2.78)\end{array}$ & $\begin{array}{l}0.008 \\
(1.18)\end{array}$ \\
\hline Leverage & $\begin{array}{c}0.502 * * * \\
(8.12)\end{array}$ & $\begin{array}{c}0.199 * * * \\
(6.59)\end{array}$ & $\begin{array}{c}-0.070 * * * \\
(-8.30)\end{array}$ \\
\hline$R O A$ & $\begin{array}{c}1.104 * * * \\
(10.03)\end{array}$ & $\begin{array}{l}0.156^{* *} \\
(2.47)\end{array}$ & $\begin{array}{l}-0.028 \\
(-1.54)\end{array}$ \\
\hline Economic Growth & $\begin{array}{l}-1.043^{*} \\
(-1.93)\end{array}$ & $\begin{array}{l}0.0220 \\
(0.16)\end{array}$ & $\begin{array}{c}-0.730 * * * \\
(-9.37)\end{array}$ \\
\hline Inflation & $\begin{array}{c}2.016^{* *} \\
(2.32)\end{array}$ & $\begin{array}{l}1.104 * * * \\
(5.25)\end{array}$ & $\begin{array}{l}-0.016 \\
(-0.14)\end{array}$ \\
\hline $\operatorname{Ln}(G D P)$ & $\begin{array}{c}1.038 * * * \\
(7.05)\end{array}$ & $\begin{array}{c}0.358 * * * \\
(10.65)\end{array}$ & $\begin{array}{l}-0.034^{*} \\
(-1.77)\end{array}$ \\
\hline English Law & $\begin{array}{l}0.626 \\
(1.60)\end{array}$ & $\begin{array}{l}0.053 \\
(1.00)\end{array}$ & $\begin{array}{c}-0.178 * * * \\
(-5.24)\end{array}$ \\
\hline French Law & $\begin{array}{l}0.484 \\
(1.06)\end{array}$ & $\begin{array}{l}0.053 \\
(0.76)\end{array}$ & $\begin{array}{l}0.118 * * * \\
(2.77)\end{array}$ \\
\hline German Law & $\begin{array}{l}1.236^{* *} \\
(2.49)\end{array}$ & $\begin{array}{c}0.248 * * * \\
(3.61)\end{array}$ & $\begin{array}{c}-0.219 * * * \\
(-5.43)\end{array}$ \\
\hline Rule of Law & $\begin{array}{c}-0.292 * * * \\
(-3.18)\end{array}$ & $\begin{array}{c}-0.161 * * * \\
(-7.59)\end{array}$ & $\begin{array}{l}-0.007 \\
(-0.58)\end{array}$ \\
\hline Political Rights & $\begin{array}{l}0.022 \\
(0.50)\end{array}$ & $\begin{array}{l}0.009 \\
(0.75)\end{array}$ & $\begin{array}{c}0.059 * * * \\
(8.83)\end{array}$ \\
\hline Creditor Rights & $\begin{array}{c}-0.120^{* *} \\
(-2.00)\end{array}$ & $\begin{array}{c}-0.035^{* *} \\
(-2.44)\end{array}$ & $\begin{array}{c}0.066^{* * *} \\
(8.96)\end{array}$ \\
\hline Public Sector Corruption & $\begin{array}{l}0.0960 \\
(0.52)\end{array}$ & $\begin{array}{c}-0.0130 \\
(-0.30)\end{array}$ & $\begin{array}{c}-0.099 * * * \\
(-4.68)\end{array}$ \\
\hline Intercept & $\begin{array}{c}-11.599 * * * \\
(-11.04)\end{array}$ & $\begin{array}{c}-1.997 * * * \\
(-8.19)\end{array}$ & $\begin{array}{c}0.350 * * * \\
(3.16)\end{array}$ \\
\hline $\begin{array}{l}\text { Loan Purpose/Loan Type } \\
\text { Industrv/Year }\end{array}$ & $\begin{array}{l}\text { Included } \\
\text { Included }\end{array}$ & $\begin{array}{l}\text { Included } \\
\text { Included }\end{array}$ & $\begin{array}{l}\text { Included } \\
\text { Included }\end{array}$ \\
\hline Number of observations & 31,414 & 22,376 & 22,376 \\
\hline Pseudo $R^{2} /$ Adjusted $R^{2}$ & 0.351 & 0.256 & 0.183 \\
\hline
\end{tabular}


Table 7: Relation between lending corruption and leverage policy

The dependent variables are Leverage, Short-term Leverage, and Long-term Leverage. The variable definitions are in Appendix A. For brevity, the coefficients for the industry and year fixed effects are not reported. The regression coefficients are reported for each variable, followed by the heteroscedasticity-robust t-statistic in parentheses. ${ }^{*}, * *$, and $* * *$ indicate statistical significance at the $10 \%, 5 \%$, and $1 \%$ levels, respectively.

\begin{tabular}{|c|c|c|c|}
\hline & $\begin{array}{c}(1) \\
\text { Leverage }\end{array}$ & $\begin{array}{c}(2) \\
\text { Short-term Leverage }\end{array}$ & $\begin{array}{c}\text { (3) } \\
\text { Long-term Leverage }\end{array}$ \\
\hline Lending Corruption & $\begin{array}{l}0.017^{* * * *} \\
(2.75)\end{array}$ & $\begin{array}{l}-0.003 \\
(-0.76)\end{array}$ & $\begin{array}{l}0.024 * * * \\
(4.98)\end{array}$ \\
\hline Tangibility & $\begin{array}{c}0.022 * * * \\
(46.96)\end{array}$ & $\begin{array}{c}-0.002 * * * \\
(-7.52)\end{array}$ & $\begin{array}{c}0.022 * * * \\
(71.77)\end{array}$ \\
\hline$R O A$ & $\begin{array}{c}-0.075^{* * *} \\
(-18.40)\end{array}$ & $\begin{array}{c}-0.037^{* * * *} \\
(-14.25)\end{array}$ & $\begin{array}{c}-0.024 * * * \\
(-12.70)\end{array}$ \\
\hline Tobin $Q$ & $\begin{array}{c}0.038 * * * \\
(24.51)\end{array}$ & $\begin{array}{c}0.025 * * * \\
(25.56)\end{array}$ & $\begin{array}{c}-0.004 * * * \\
(-4.97)\end{array}$ \\
\hline Prob. Bankruptcy & $\begin{array}{c}0.517 * * * \\
(64.78)\end{array}$ & $\begin{array}{c}0.303 * * * \\
(57.81)\end{array}$ & $\begin{array}{c}0.136 * * * \\
(32.62)\end{array}$ \\
\hline Economic Growth & $\begin{array}{l}-0.012 \\
(-0.75)\end{array}$ & $\begin{array}{c}-0.059^{* * * *} \\
(-5.42)\end{array}$ & $\begin{array}{l}0.058^{* * *} \\
(5.35)\end{array}$ \\
\hline Inflation & $\begin{array}{c}-0.002 * * * \\
(-10.80)\end{array}$ & $\begin{array}{l}-0.000 \\
(-0.61)\end{array}$ & $\begin{array}{c}-0.002 * * * \\
(-15.24)\end{array}$ \\
\hline $\operatorname{Ln}(G D P)$ & $\begin{array}{c}-0.034 * * * \\
(-9.22)\end{array}$ & $\begin{array}{c}-0.019^{* * * *} \\
(-8.56)\end{array}$ & $\begin{array}{c}-0.015^{* * *} \\
(-5.43)\end{array}$ \\
\hline English Law & $\begin{array}{c}0.083 * * * \\
(9.01)\end{array}$ & $\begin{array}{l}0.006 \\
(1.25)\end{array}$ & $\begin{array}{c}0.072 * * * \\
(10.10)\end{array}$ \\
\hline French Law & $\begin{array}{c}0.083^{* * * *} \\
(8.04)\end{array}$ & $\begin{array}{l}0.059 * * * \\
(10.92)\end{array}$ & $\begin{array}{c}0.019^{* *} \\
(2.34)\end{array}$ \\
\hline German Law & $\begin{array}{c}0.050 * * * \\
(4.55)\end{array}$ & $\begin{array}{c}0.026^{* * *} \\
(4.40)\end{array}$ & $\begin{array}{l}0.014 * \\
(1.66)\end{array}$ \\
\hline Rule of Law & $\begin{array}{c}0.029 * * * \\
(13.91)\end{array}$ & $\begin{array}{c}0.011 * * * \\
(8.83)\end{array}$ & $\begin{array}{c}0.018 * * * \\
(11.80)\end{array}$ \\
\hline Political Rights & $\begin{array}{c}-0.002 * * \\
(-2.05)\end{array}$ & $\begin{array}{c}-0.015 * * * \\
(-18.67)\end{array}$ & $\begin{array}{c}0.014 * * * \\
(16.62)\end{array}$ \\
\hline Creditor Rights & $\begin{array}{c}0.00200 \\
(1.49)\end{array}$ & $\begin{array}{c}0.008 * * * \\
(9.04)\end{array}$ & $\begin{array}{c}-0.005^{* * *} \\
(-4.98)\end{array}$ \\
\hline Public Sector Corruption & $\begin{array}{c}0.012 * * \\
(2.32)\end{array}$ & $\begin{array}{c}0.011 * * * \\
(2.98)\end{array}$ & $\begin{array}{l}0.000 \\
(0.12)\end{array}$ \\
\hline Intercept & $\begin{array}{c}0.052^{* *} \\
(1.98)\end{array}$ & $\begin{array}{c}0.224 * * * \\
(14.13)\end{array}$ & $\begin{array}{c}-0.151^{* * *} \\
(-7.99)\end{array}$ \\
\hline Industry/Year & Included & Included & Included \\
\hline Number of observations & 94,673 & 94,673 & 94,673 \\
\hline Adjusted $R^{2}$ & 0.298 & 0.316 & 0.159 \\
\hline
\end{tabular}




\section{Table 8: Relation between lending corruption and debt choice}

The dependent variables are Bank Debt Ratio and Public Debt Ratio. The variable definitions are in Appendix A. For brevity, the coefficients for the industry and year fixed effects are not reported. The regression coefficients are reported for each variable, followed by the heteroscedasticity-robust t-statistic in parentheses. *, **, and *** indicate statistical significance at the $10 \%, 5 \%$, and $1 \%$ levels, respectively.

\begin{tabular}{|c|c|c|}
\hline & $\begin{array}{c}\text { (1) } \\
\text { Bank Debt Ratio }\end{array}$ & $\begin{array}{c}\text { (2) } \\
\text { Public Debt Ratio }\end{array}$ \\
\hline Lending Corruption & $\begin{array}{c}0.085 * * * \\
(5.91)\end{array}$ & $\begin{array}{c}-0.045 * * * \\
(-3.24)\end{array}$ \\
\hline Ln (Firm Size) & $\begin{array}{c}-0.045 * * * \\
(-45.58)\end{array}$ & $\begin{array}{c}0.043 * * * \\
(42.67)\end{array}$ \\
\hline$R O A$ & $\begin{array}{c}0.027 * * * \\
(6.29)\end{array}$ & $\begin{array}{c}-0.023 * * * \\
(-5.20)\end{array}$ \\
\hline Tobin $Q$ & $\begin{array}{c}-0.031 * * * \\
(-11.63)\end{array}$ & $\begin{array}{c}0.032 * * * \\
(11.85)\end{array}$ \\
\hline Prob. Bankruptcy & $\begin{array}{c}-0.144 * * * \\
(-13.25)\end{array}$ & $\begin{array}{c}0.135 * * * \\
(12.11)\end{array}$ \\
\hline Economic Growth & $\begin{array}{c}0.131 * * * \\
(3.50)\end{array}$ & $\begin{array}{c}-0.097 * * * \\
(-2.67)\end{array}$ \\
\hline Inflation & $\begin{array}{c}0.003 * * \\
(2.39)\end{array}$ & $\begin{array}{l}-0.002 \\
(-1.34)\end{array}$ \\
\hline $\operatorname{Ln}(G D P)$ & $\begin{array}{c}-0.124 * * * \\
(-14.27)\end{array}$ & $\begin{array}{c}0.124 * * * \\
(14.54)\end{array}$ \\
\hline English Law & $\begin{array}{c}-0.100 * * * \\
(-3.35)\end{array}$ & $\begin{array}{c}0.111 * * * \\
(3.72)\end{array}$ \\
\hline French Law & $\begin{array}{l}0.030 \\
(0.92)\end{array}$ & $\begin{array}{l}-0.045 \\
(-1.39)\end{array}$ \\
\hline German Law & $\begin{array}{c}-0.098 * * * \\
(-2.87)\end{array}$ & $\begin{array}{l}0.0430 \\
(1.26)\end{array}$ \\
\hline Rule of Law & $\begin{array}{c}0.020 * * * \\
(3.53)\end{array}$ & $\begin{array}{l}-0.001 \\
(-0.23)\end{array}$ \\
\hline Political Rights & $\begin{array}{c}0.012 * * * \\
(3.64)\end{array}$ & $\begin{array}{c}-0.017 * * * \\
(-5.14)\end{array}$ \\
\hline Creditor Rights & $\begin{array}{c}0.031 * * * \\
(8.30)\end{array}$ & $\begin{array}{c}-0.024 * * * \\
(-6.41)\end{array}$ \\
\hline Public Sector Corruption & $\begin{array}{c}-0.070 * * * \\
(-5.31)\end{array}$ & $\begin{array}{c}0.084 * * * \\
(6.49)\end{array}$ \\
\hline Intercept & $\begin{array}{l}1.616^{* * *} \\
(21.27)\end{array}$ & $\begin{array}{c}-0.851 * * * \\
(-11.34)\end{array}$ \\
\hline Industry/Year & Included & Included \\
\hline Number of observations & 22,638 & 22,638 \\
\hline Adjusted $R^{2}$ & 0.169 & 0.181 \\
\hline
\end{tabular}


Table 9: Relationship between lending corruption, loan quality, and bank performance

The dependent variables are Bank NPL, Bank LLR and Bank ROA. The variable definitions are in Appendix A. For brevity, the coefficients for the industry and year fixed effects are not reported. The regression coefficients are reported for each variable, followed by the heteroscedasticity-robust t-statistic in parentheses. $*, * *$, and $* * *$ indicate statistical significance at the $10 \%, 5 \%$, and $1 \%$ levels, respectively.

\begin{tabular}{|c|c|c|c|}
\hline & $\begin{array}{c}(1) \\
\text { Bank NPL }\end{array}$ & $\begin{array}{c}(2) \\
\text { Bank LLR }\end{array}$ & $\begin{array}{c}\text { (3) } \\
\text { Bank ROA }\end{array}$ \\
\hline Lending Corruption & $\begin{array}{c}0.007 * * \\
(2.49)\end{array}$ & $\begin{array}{c}0.023 * * * \\
(6.43)\end{array}$ & $\begin{array}{c}-0.004 * * * \\
(-6.88)\end{array}$ \\
\hline Bank Size & $\begin{array}{c}-0.001 * * * \\
(-5.50)\end{array}$ & $\begin{array}{c}-0.002 * * * \\
(-7.41)\end{array}$ & $\begin{array}{c}0.001 * * * \\
(39.22)\end{array}$ \\
\hline Bank Growth & $\begin{array}{c}-0.027 * * * \\
(-6.43)\end{array}$ & $\begin{array}{c}-0.077 * * * \\
(-9.58)\end{array}$ & $\begin{array}{c}-0.026 * * * \\
(-21.96)\end{array}$ \\
\hline Bank Equity & $\begin{array}{c}-0.003 * * * \\
(-3.05)\end{array}$ & $\begin{array}{c}-0.008 * * * \\
(-3.44)\end{array}$ & $\begin{array}{c}0.002 * * * \\
(5.52)\end{array}$ \\
\hline Bank Big & $\begin{array}{c}-0.059 * * * \\
(-2.71)\end{array}$ & $\begin{array}{l}0.016 \\
(0.36)\end{array}$ & $\begin{array}{c}0.329 * * * \\
(43.82)\end{array}$ \\
\hline Bank State-owned & $\begin{array}{c}0.016^{* * *} \\
(4.71)\end{array}$ & $\begin{array}{c}0.013 * * * \\
(2.59)\end{array}$ & $\begin{array}{c}-0.005 * * * \\
(-10.79)\end{array}$ \\
\hline Bank Listed & $\begin{array}{c}-0.004 * * * \\
(-8.30)\end{array}$ & $\begin{array}{c}-0.004 * * * \\
(-5.05)\end{array}$ & $\begin{array}{l}0.000 \\
(1.50)\end{array}$ \\
\hline Bank IFRS & $\begin{array}{c}-0.011 * * * \\
(-4.34)\end{array}$ & $\begin{array}{c}0.016^{* * *} \\
(7.63)\end{array}$ & $\begin{array}{l}0.000 \\
(1.16)\end{array}$ \\
\hline Economic Growth & $\begin{array}{c}-0.104 * * * \\
(-16.37)\end{array}$ & $\begin{array}{c}-0.064 * * * \\
(-8.04)\end{array}$ & $\begin{array}{c}0.013 * * * \\
(11.00)\end{array}$ \\
\hline Inflation & $\begin{array}{c}-0.000 * * * \\
(-3.44)\end{array}$ & $\begin{array}{c}0.000 * * * \\
(3.06)\end{array}$ & $\begin{array}{c}0.000 * * * \\
(3.23)\end{array}$ \\
\hline $\operatorname{Ln}(G D P)$ & $\begin{array}{c}-0.025 * * * \\
(-27.47)\end{array}$ & $\begin{array}{c}-0.018^{* * *} \\
(-13.65)\end{array}$ & $\begin{array}{c}0.002 * * * \\
(13.15)\end{array}$ \\
\hline English Law & $\begin{array}{c}0.007 * * \\
(2.11)\end{array}$ & $\begin{array}{c}-0.008 * * * \\
(-3.63)\end{array}$ & $\begin{array}{l}0.000 \\
(0.72)\end{array}$ \\
\hline French Law & $\begin{array}{c}0.023 * * * \\
(7.36)\end{array}$ & $\begin{array}{c}0.024 * * * \\
(9.91)\end{array}$ & $\begin{array}{c}-0.007 * * * \\
(-12.79)\end{array}$ \\
\hline German Law & $\begin{array}{c}0.050 * * * \\
(12.51)\end{array}$ & $\begin{array}{c}0.012 * * * \\
(4.37)\end{array}$ & $\begin{array}{c}-0.005 * * * \\
(-7.49)\end{array}$ \\
\hline Rule of Law & $\begin{array}{c}0.011 * * * \\
(2.75)\end{array}$ & $\begin{array}{l}-0.006 \\
(-1.46)\end{array}$ & $\begin{array}{l}0.001 \\
(1.10)\end{array}$ \\
\hline Political Rights & $\begin{array}{c}-0.005^{* * * *} \\
(-6.03)\end{array}$ & $\begin{array}{c}-0.002 * * * \\
(-2.61)\end{array}$ & $\begin{array}{c}0.000 * * * \\
(3.08)\end{array}$ \\
\hline Creditor Rights & $\begin{array}{c}0.004 * * * \\
(3.70)\end{array}$ & $\begin{array}{c}-0.007 * * * \\
(-7.69)\end{array}$ & $\begin{array}{l}0.000 \\
(0.88)\end{array}$ \\
\hline Public Sector Corruption & $\begin{array}{c}0.009 * * \\
(2.56)\end{array}$ & $\begin{array}{c}-0.010 * * \\
(-2.48)\end{array}$ & $\begin{array}{c}0.004 * * * \\
(6.09)\end{array}$ \\
\hline Intercept & $\begin{array}{c}0.323 * * * \\
(25.28)\end{array}$ & $\begin{array}{c}0.279 * * * \\
(16.00)\end{array}$ & $\begin{array}{c}0.012 * * * \\
(5.23)\end{array}$ \\
\hline Year & Included & Included & Included \\
\hline Number of observations & 93,032 & 104,411 & 128,835 \\
\hline Adjusted $R^{2}$ & 0.397 & 0.159 & 0.187 \\
\hline
\end{tabular}


Table 10: Relationship between lending corruption and bank trouble during the financial crisis

The dependent variable is Bank Trouble. The variable definitions are in Appendix A. The regression coefficients are reported for each variable, followed by the heteroscedasticity-robust z-statistic in parentheses. $* * *$, and $* * *$ indicate statistical significance at the $10 \%, 5 \%$, and $1 \%$ levels, respectively.

\begin{tabular}{|c|c|}
\hline & $\begin{array}{c}(1) \\
\text { Bank Trouble }\end{array}$ \\
\hline Lending Corruption & $\begin{array}{c}0.834 * * \\
(2.07)\end{array}$ \\
\hline Bank Size & $\begin{array}{c}0.270 * * * \\
(17.82)\end{array}$ \\
\hline Bank Growth & $\begin{array}{c}1.836^{* * *} \\
(12.41)\end{array}$ \\
\hline Bank Equity & $\begin{array}{c}-2.316 * * * \\
(-4.86)\end{array}$ \\
\hline Bank Big & $\begin{array}{c}7.653 * * * \\
(4.86)\end{array}$ \\
\hline Bank State-owned & $\begin{array}{l}9.119 * * \\
(2.55)\end{array}$ \\
\hline Bank Listed & $\begin{array}{l}-0.614^{*} \\
(-1.72)\end{array}$ \\
\hline Bank IFRS & $\begin{array}{c}0.942^{* *} \\
(2.23)\end{array}$ \\
\hline Economic Growth & $\begin{array}{c}-18.042 * * * \\
(-4.11)\end{array}$ \\
\hline Inflation & $\begin{array}{c}0.247 * * * \\
(4.07)\end{array}$ \\
\hline $\operatorname{Ln}(G D P)$ & $\begin{array}{l}0.268 \\
(1.04)\end{array}$ \\
\hline English Law & $\begin{array}{l}0.444 \\
(1.02)\end{array}$ \\
\hline French Law & $\begin{array}{c}-0.947 * \\
(-1.82)\end{array}$ \\
\hline German Law & $\begin{array}{l}-0.276 \\
(-0.15)\end{array}$ \\
\hline Rule of Law & $\begin{array}{l}-1.577 \\
(-1.45)\end{array}$ \\
\hline Political Rights & $\begin{array}{l}-0.135 \\
(-1.00)\end{array}$ \\
\hline Creditor Rights & $\begin{array}{c}-0.524 * * * \\
(-2.65)\end{array}$ \\
\hline Public Sector Corruption & $\begin{array}{l}-1.433 \\
(-1.36)\end{array}$ \\
\hline Intercept & $\begin{array}{l}-3.316 \\
(-1.27)\end{array}$ \\
\hline $\begin{array}{l}\text { Number of observations } \\
\text { Pseudo } R^{2}\end{array}$ & $\begin{array}{l}9,970 \\
0.049\end{array}$ \\
\hline
\end{tabular}




\section{Table 11: Relation between lending corruption and bank loan contracting: Excluding US}

The dependent variables are Ln (Loan Spread), Ln (Loan Size), and Ln (Maturity). The variable definitions are in Appendix A. For brevity, the coefficients for the industry, year, loan purpose, and loan type fixed effects are not reported. The regression coefficients are reported for each variable, followed by the heteroscedasticity-robust t-statistic in parentheses. $*, * *$, and $* * *$ indicate statistical significance at the $10 \%$, $5 \%$, and $1 \%$ levels, respectively.

\begin{tabular}{|c|c|c|c|}
\hline & $\begin{array}{c}(1) \\
\text { Ln (Loan Spread) }\end{array}$ & $\begin{array}{c}(2) \\
\text { Ln (Loan Size) }\end{array}$ & $\begin{array}{c}(3) \\
\text { Ln (Loan Maturity) }\end{array}$ \\
\hline Lending Corruption & $\begin{array}{c}-0.997 * * * \\
(-7.97)\end{array}$ & $\begin{array}{c}0.184 * * * \\
(5.12)\end{array}$ & $\begin{array}{c}0.142^{* *} \\
(2.28)\end{array}$ \\
\hline Ln (Loan Size) & $\begin{array}{c}-0.546^{* * *} \\
(-10.05)\end{array}$ & & $\begin{array}{l}-0.029 \\
(-0.76)\end{array}$ \\
\hline Ln (Loan Maturity) & $\begin{array}{c}0.105^{* * *} \\
(4.85)\end{array}$ & $\begin{array}{l}-0.004 \\
(-0.76)\end{array}$ & \\
\hline Performance Pricing & $\begin{array}{c}0.172 * * * \\
(5.61)\end{array}$ & $\begin{array}{c}0.094 * * * \\
(7.15)\end{array}$ & $\begin{array}{c}0.049^{*} \\
(1.73)\end{array}$ \\
\hline Ln (Firm Size) & $\begin{array}{c}-0.107 * * * \\
(-10.11)\end{array}$ & $\begin{array}{c}0.067 * * * \\
(26.47)\end{array}$ & $\begin{array}{c}-0.025^{* * *} \\
(-3.94)\end{array}$ \\
\hline Tangibility & $\begin{array}{c}-0.083^{*} \\
(-1.82)\end{array}$ & $\begin{array}{l}-0.018 \\
(-1.49)\end{array}$ & $\begin{array}{c}-0.076^{* *} \\
(-2.35)\end{array}$ \\
\hline Leverage & $\begin{array}{c}0.397 * * * \\
(5.75)\end{array}$ & $\begin{array}{c}-0.071 * * * \\
(-3.51)\end{array}$ & $\begin{array}{c}0.138 * * * \\
(2.79)\end{array}$ \\
\hline$R O A$ & $\begin{array}{c}-1.168 * * * \\
(-6.98)\end{array}$ & $\begin{array}{c}-0.132 * * * \\
(-3.50)\end{array}$ & $\begin{array}{l}0.167^{*} \\
(1.81)\end{array}$ \\
\hline Economic Growth & $\begin{array}{l}-0.175 \\
(-0.93)\end{array}$ & $\begin{array}{c}-0.196 * * * \\
(-3.63)\end{array}$ & $\begin{array}{l}0.060 \\
(0.38)\end{array}$ \\
\hline Inflation & $\begin{array}{c}1.415 * * * \\
(5.57)\end{array}$ & $\begin{array}{c}-0.372 * * * \\
(-6.36)\end{array}$ & $\begin{array}{c}-1.287 * * * \\
(-6.30)\end{array}$ \\
\hline $\operatorname{Ln}(G D P)$ & $\begin{array}{c}0.156^{* * * *} \\
(2.99)\end{array}$ & $\begin{array}{l}0.023 \\
(1.46)\end{array}$ & $\begin{array}{c}-0.081 * * \\
(-2.24)\end{array}$ \\
\hline English Law & $\begin{array}{c}0.291 * * * \\
(4.31)\end{array}$ & $\begin{array}{l}-0.041 \\
(-1.55)\end{array}$ & $\begin{array}{c}-0.353^{* * * *} \\
(-6.69)\end{array}$ \\
\hline French Law & $\begin{array}{c}-0.274 * * * \\
(-2.80)\end{array}$ & $\begin{array}{l}-0.012 \\
(-0.37)\end{array}$ & $\begin{array}{l}-0.080 \\
(-1.17)\end{array}$ \\
\hline German Law & $\begin{array}{c}0.679 * * * \\
(6.57)\end{array}$ & $\begin{array}{l}-0.051 \\
(-1.43)\end{array}$ & $\begin{array}{c}-0.361^{* * *} \\
(-5.22)\end{array}$ \\
\hline Rule of Law & $\begin{array}{c}-0.080^{* *} \\
(-2.15)\end{array}$ & $\begin{array}{c}0.025 * * * \\
(2.85)\end{array}$ & $\begin{array}{l}0.000 \\
(0.02)\end{array}$ \\
\hline Political Rights & $\begin{array}{c}-0.179 * * * \\
(-5.84)\end{array}$ & $\begin{array}{c}0.038 * * * \\
(7.57)\end{array}$ & $\begin{array}{c}0.061 * * * \\
(5.54)\end{array}$ \\
\hline Creditor Rights & $\begin{array}{c}-0.201 * * * \\
(-8.33)\end{array}$ & $\begin{array}{c}0.028 * * * \\
(4.70)\end{array}$ & $\begin{array}{c}0.059 * * * \\
(4.71)\end{array}$ \\
\hline Public Sector Corruption & $\begin{array}{c}0.326^{* * *} \\
(4.27)\end{array}$ & $\begin{array}{l}0.015 \\
(0.94)\end{array}$ & $\begin{array}{c}-0.140 * * * \\
(-3.56)\end{array}$ \\
\hline Intercept & $\begin{array}{l}7.093^{* * *} \\
(12.44)\end{array}$ & $\begin{array}{c}-1.142 * * * \\
(-7.71)\end{array}$ & $\begin{array}{c}4.652 * * * \\
(15.01)\end{array}$ \\
\hline Loan Purpose/Loan Type & Included & Included & Included \\
\hline Industry/Year & Included & Included & Included \\
\hline Number of observations & 2,269 & 5,370 & 5,370 \\
\hline Adjusted $R^{2}$ & 0.534 & 0.337 & 0.140 \\
\hline
\end{tabular}

